ISSN: 0213-2060

DOI: https://doi.org/10.14201/shhme202038181112

\title{
ENTERRAMIENTOS Y RITOS FUNERARIOS ISLÁMICOS: DE LO ANDALUSÍ A LO MUDÉJAR A TRAVÉS DEL CASO TOLEDANO
}

\author{
Islamic Burials and Funerary Rites. Toledo as a Case-Study for the Evolution from \\ Andalusi to Mudejar \\ Ana ECHEVARRÍA \\ Depto. de Historia Medieval y Ciencias y Técnicas Historiográficas. Facultad de Geografía e Historia. Universidad \\ Nacional de Educación a Distancia (UNED). C/ Senda del Rey,n.0 7. E-28040 MADRID. C. e.: aechevarria@ \\ geo.uned.es
}

Recibido: 2019-11-16

Revisado: 2020-02-24

Aceptado: 2020-05-04

RESUMEN: Este artículo propone utilizar los resultados de las diversas excavaciones de necrópolis toledanas junto con fuentes escritas cristianas y árabes sobre la situación de los cementerios en la ciudad y las limitaciones prácticas que se imponían sobre ellos, así como el corpus de literatura religiosa escrita por los propios musulmanes, compuesto de tratados teóricos de derecho islámico (fiqh), breviarios musulmanes (uno de ellos procedente de Ocaña, población vecina a la ciudad e inscrita en su órbita cultural) y las actas de las reuniones de una cofradía mudéjar sufí toledana activa entre 1400 y 1420, para mostrar las líneas de continuidad y ruptura existentes entre la población islámica de la Meseta desde el periodo andalusí al mudéjar.

Palabras clave: Arqueología funeraria; Al-Andalus; Ritos funerarios islámicos; Cementerio; Mudéjares.

ABSTRACT: This article will use a range of sources to show traces of continuity or breakdown among the Islamic population of Toledo from Andalusi to Mudejar times. The archaeological information from the campaigns in Toledo's cemeteries will provide a contrast with Christian and Arabic written sources about the location of their grounds and the practical limitations accorded by Christians to burial customs. The corpus of Islamic literature includes theoretical treatises of fiqh. Islamic breviaries -one of them from Ocaña, a nearby town in the cultural zone of influence of Toledo- and the proceedings of the meetings of a sufi confraternity in Toledo (active c. 1400-1420).

Keywords: Funerary archaeology; Al-Andalus; Islamic funerary rites; Cemeteries; Mudejars. 
ENTERRAMIENTOS Y RITOS FUNERARIOS ISLÁMICOS:

DE LO ANDALUSÍ A LO MUDÉJAR A TRAVÉS DEL CASO TOLEDANO

ANA ECHEVARRÍA

SUMARIO: 0 Introducción. 1 El cementerio andalusí y sus características. 2 Los recintos funerarios de Toledo durante la época islámica. 3 De cementerio andalusí a cementerio mudéjar: ¿continuidad de los espacios funerarios? 4 La regulación de los enterramientos mudéjares por las autoridades cristianas. 5 Rituales vinculados con la muerte según las fuentes escritas mudéjares del entorno toledano. $6 \mathrm{El}$ fin del cementerio mudéjar. 7 Referencias bibliográficas.

\section{INTRODUCCIÓN}

El campo de lo funerario es una perspectiva privilegiada para observar el hecho religioso y hasta qué punto este se convierte en definitorio de la identidad de un grupo social. Enfrentados a la muerte y la salvación del alma, los hombres medievales se apresuraban a manifestar sus creencias sin tapujos, incluso en las situaciones más desfavorables, como podían ser las de sometimiento religioso a una comunidad de otro signo. Igualmente, el mundo funerario permite identificar factores de continuidad y cambio entre los periodos andalusí y mudéjar de la Península, debido a la congelación en el tiempo de los restos inhumados, pero también a las fuentes literarias, que nos aproximan a los aspectos sociales que envuelven a la muerte.

La elección del caso de Toledo para este artículo parte de la riqueza y variedad de las fuentes para su estudio: se han realizado diversas excavaciones de necrópolis toledanas de distinto periodo y adscripción religiosa; existen lápidas y cipos con inscripciones comparables a las de otros cementerios islámicos; contamos con fuentes escritas cristianas y árabes sobre la situación de los cementerios en la ciudad y las limitaciones prácticas que se imponían sobre ellos; y existe un corpus de literatura religiosa escrita por los propios musulmanes, compuesto de breviarios castellanos (uno de ellos procedente de Ocaña, población vecina a la ciudad e inscrita en su órbita cultural) y por las actas de las reuniones de una cofradía mudéjar toledana. Todo ello nos permite trazar un panorama contrastado que cubre la mayor parte de las manifestaciones de lo funerario.

Desde el punto de vista histórico, Toledo tiene una serie de particularidades que permiten comparar sus necrópolis con otras ya estudiadas anteriormente, como las de Ávila o Murcia. Se trata de una conquista temprana, en el siglo XI, y de un lugar en la Meseta Sur en el que las condiciones geográficas condicionan seriamente la elección del suelo funerario, a la vez que cuenta con una población numerosa y continuada en el tiempo, frente al abandono temporal de algunas ciudades de la cuenca del Duero. Creemos que un estudio sistemático de la tradición funeraria islámica en la ciudad permitiría resolver las dudas planteadas sobre la continuidad de la población islámica después de la conquista, que supuestamente utilizaría las mismas zonas de enterramiento. En eso se diferenciaría de los cementerios islámicos de la cuenca del Duero, condicionados por la formación de unas comunidades mudéjares de emigración, que negociarían la implantación de sus necrópolis directamente con las autoridades cristianas, sin contar con precedentes. 


\section{EL CEMENTERIO ANDALUSÍ Y SUS CARACTERÍSTICAS}

Antes de abordar el caso concreto de Toledo, parece conveniente comenzar por unas notas generales sobre la configuración de los cementerios islámicos, en general, y andalusíes, en particular. La palabra castellana almacabra, deriva del árabe al-maqbara, que designa tanto la lápida como el recinto de la necrópolis, y que se ha popularizado actualmente entre los especialistas para referirse a los cementerios islámicos de la Edad Media ${ }^{1}$. Sin embargo, esta no es la única denominación utilizada en las fuentes árabes, que también utilizan qubūr, el plural que designa enterramientos islámicos, mientras que el término rauda (del árabe rawda, jardín) se aplicaba a los mausoleos o panteones de príncipes y personajes destacados ${ }^{2}$. Al contrario que en el cristianismo, donde el cementerio tendía a agruparse en torno a una parroquia, dentro de ella o rodeando el mausoleo de santos venerados, los cementerios islámicos no podían estar dentro ni en torno a una mezquita (su situación en torno a tumbas de santones sería una derivación tardía), y tampoco se permitía construir una mezquita en su interior, al modo de las capillas funerarias existentes en cementerios cristianos extensos. La necesidad de mantener ciertas convenciones higiénicas y disponer de accesos fáciles hizo que se situaran fuera de los recintos amurallados, cerca normalmente de un curso de agua o del mar y con acceso desde una o varias puertas de la ciudad. Por otra parte, la presión demográfica en las grandes ciudades andalusíes hizo que los cementerios -en los que según el rito malikí los difuntos debían enterrarse directamente sobre el suelo- ocuparan grandes extensiones de terreno rodeando la parte ocupada por los vivos. Aunque a veces aparece alguna tumba en el interior del recinto amurallado, como veremos más adelante, la mayoría se sitúa en los suburbios (llamados hawmà en las fuentes árabes) ${ }^{3}$.

Cada tumba podía ser marcada de formas diversas, en materiales que respondían a la facilidad de consecución sobre el terreno o a la diversificación social de las zonas de habitación a las que servían. Estos marcadores recibían el nombre de šăhid (testigo) y en la Meseta castellana solían ser lápidas que se colocaban sobre la superficie de la tierra excavada para depositar el cuerpo. Aunque las escuelas de derecho, concretamente la malikí, recomendaban que no se erigieran monumentos excesivamente ricos sobre la tumba

1 Agradezco a los evaluadores sus acertadas sugerencias. Burton-PAGE, J. «Makbara». Encyclopedia of Islam. 2.a ed. Leiden: Brill, 1991, vol. VI, pp. 122-128; Pinilla Melguizo, Rafael. "Aportaciones al estudio de la topografía de la Córdoba islámica: almacabras». Qurtuba, 1997, vol. 2, pp. 175-214; JiméNez GADEA, Javier. «Estelas funerarias islámicas de Ávila: clasificación e inscripciones». Espacio, Tiempo y Forma. Serie I, Nueva época. Prehistoria y Arqueología, 2009, vol. 2, pp. 221-267, concretamente pp. 223-224; HalevI, Leor. Muhammad's grave. Death Rites and the making of Islamic Society. New York: Columbia University Pres, 2007, p. 147.

2 Torres Balbás, Leopoldo, «Diario de obras en La Alhambra, 1925-1926». Cuadernos de La Alhambra, 1967, vol. 3, pp. 125-152; Bulle, Tuil. «L'architecture funéraire de Fès. Étude préliminaire d'une rawḍa anonyme». Arqueología Medieval, 2012, vol. 12, pp. 257-270; Alemán Aguilera, Inmaculada; BotelLA López, Miguel Cecilio y Jiménez Brobeil, Sylvia Alejandra. «Estudio antropológico de los restos óseos humanos aparecidos en el cementerio de La Rauda». Cuadernos de la Alhambra, 2000, vol. 36, pp. 181-190.

3 Valor, Magdalena y GutiérRez, José Avelino (coords.). The Archaeology of Medieval Spain, 11001500. Sheffield: Equinox, 2014, pp. 242-243; Torres Palomo, María Paz y Acién Almansa, Manuel Pedro (eds.). Estudios sobre cementerios islámicos andalusies. Málaga: Universidad de Málaga, 1995. 
ENTERRAMIENTOS Y RITOS FUNERARIOS ISLÁMICOS:

DE LO ANDALUSÍ A LO MUDÉJAR A TRAVÉS DEL CASO TOLEDANO

ANA ECHEVARRÍA

de un personaje islámico, aduciendo que todos somos iguales en la muerte ante los ojos de Dios, en la mayor parte de los dominios del Islam se mantuvo la tradición de origen romano-bizantino de erigir monumentos más o menos ornamentados para panteones familiares y de gobernantes. En otros casos, se aprovecharon estructuras ya construidas, como mausoleos de etapas previas. Los cementerios andalusíes se caracterizan por identificar a los musulmanes mediante lápidas (rujāma, lawh), estas sí permitidas por los juristas malikíes, que las preferían a los mausoleos u otro tipo de construcciones, que debían evitar estar techadas ${ }^{4}$. Aunque se recomendaba que fueran planas, sin inscripción, de forma que el fallecido se mostrara humilde en su anonimato y ausencia de rango, los andalusíes recurrieron a las inscripciones coránicas, que, sin mencionar al individuo, buscaban congraciarlo con Dios, acompañadas del nombre del difunto ${ }^{5}$. El escaso ajuar funerario consistía normalmente en pendientes, brazaletes, collares de perlas y algún objeto de uso cotidiano ${ }^{6}$.

Los rituales solían ser similares en toda la Península. Varios tratados legales orientales bien conocidos en al-Andalus, como el Tafrī de Ibn al-Ŷallāb (siglo x) o el Compendio de derecho islámico de al-Qayrawānī (m. 996) se ocupan de describir los rituales funerarios islámicos. Se ponía especial cuidado en qué partes del cuerpo podían ser vistas y por quién exactamente al realizar los lavados y preparativos del cuerpo del finado ${ }^{7}$. Las mortajas eran un símbolo importante de la situación social del difunto, pero las tradiciones más antiguas en cuanto al número impar de mortajas que debían envolver al cuerpo, y su sencillez, son destacados por encima de todo ${ }^{8}$. Las prácticas consuetudinarias en torno al lecho del difunto incluyen varias cuestiones problemáticas a ojos de los alfaquíes, siempre temerosos de las innovaciones, como contratar a plañideras que no fueran de la familia

4 Fierro, Maribel. «El espacio de los muertos: fetuas andalusíes sobre tumbas y cementerios». En Fierro, Maribel; Van Stä̈vel, Jean-Pierre y Cressier, Patrice (eds.). L'urbanisme dans l'Occident musulman au Moyen Âge. Aspects juridiques. Madrid: Casa de Velázquez-Consejo Superior de Investigaciones Científicas, 2000, pp. 153-189, concretamente pp. 155-157, 166-170, 179-180 y 186-188; Halevi, Muhammad's grave, pp. 32-34 y 40-42.

Delgado Valero, Clara. «La estructura urbana de Toledo en la época islámica». En Regreso a Tulaytula. Guía del Toledo islámico (siglos VIII-XI). Toledo: Junta de Comunidades de Castilla-La Mancha, 1999, pp. 15-155, concretamente p. 152.

6 Aparecen en todos los yacimientos, pero solo en una pequeńa parte de las tumbas excavadas, lo que podría deberse a su expolio o a su estudio fuera de contexto. Trelis Martí, Julio; Ortega Pérez, José Ramón; Reina Gómez, Inmaculada y Esquembre Bebia, Marco Aurelio. «El cementerio mudéjar del Raval (Crevillent-Alicante)». Arqueología y Territorio Medieval, 2009, vol. 16, pp. 179-216, especialmente pp. 188-189; Moreda Blanco, Francisco Javier y Serrano Noriega, Rosalía. «Excavación arqueológica en el cementerio de rito islámico de San Nicolás. Ávila (mayo-junio de 2002)». Oppidum, 2008, vol. 4, pp. 185212 .

Al-Qayrawānī, Abd-'Allāh Ibn Abī Zayd. Compendio de derecho islámico, trad. Jesús Riosalido. Madrid: Editorial Trotta, 1993, p. 87; Aвboud-Haggar, Soha (ed.). El tratado jurídico de al-Tafrī’ de Ibn al-Ǧallab. Manuscrito aljamiado de Almonacid de la Sierra. Zaragoza: Institución Fernando el Católico, 1999, vol. II, pp. 172-173. Utilizo esta edición aljamiada del texto, simplificada, puesto que ya ofrece una versión al castellano realizada por los propios mudéjares, y por tanto puede comunicar el sentido del texto mejor que una versión moderna.

8 Halevi, Muhammad's grave, pp. 85-87. 
para acompañar al cortejo fúnebre ${ }^{9}$. El Tafrì ‘ da las instrucciones necesarias para cavar una tumba y para la colocación del muerto en la postura preceptiva:

\begin{abstract}
Dixo Malik: Y metan el muerto en su fuesa sobrel costado el derecho, de cara enta l-alqibla. Y si no podrá ser aquello, sea puesto sobre sus espaldas y de cara enta l-alqibla. Y no ay a quien es asentado en la fuesa a su envolverlo cosa asignada de que sea sobre un par o sobre una, enpero asiente[n] sobre cantidad de lo ques neçesario a él y esté enello. Y no sea labrada de aljez (yeso) la fuesa, ni fraguada de obras de fraguamientos; y cubranla y no la aplanen mucho. Y súbanla de la tierra un poco en cantidad de lo que se puede conoçer con ello. Y bien puede concreçer la fuesa y no ay ad aquello tasa-/fol. 180r/-çion ni asignaçion conprendida, ni ora conprendida ${ }^{10}$.
\end{abstract}

\title{
2 LOS RECINTOS FUNERARIOS DE TOLEDO DURANTE LA ÉPOCA ISLÁMICA
}

Los cementerios toledanos medievales han recibido bastante atención por parte de los arqueólogos recientemente, al hilo de la expansión urbana de la ciudad y sus modificaciones durante la ocupación islámica y, posteriormente, cristiana. De hecho, los resultados de estas investigaciones deberían servir para contrastar los datos de las fuentes sobre la permanencia de cristianos en Toledo después de la llegada de los musulmanes y su progresiva asimilación, y la presunta desaparición de los musulmanes de la ciudad después de la conquista cristiana. Sin embargo, se ha prestado más atención a cuestiones puntuales como la localización de los cementerios y el tipo de tumbas allí presentes, así como a los intentos de diferenciación de los enterramientos de cada una de las tres religiones en la ciudad que es el símbolo por antonomasia de la "convivencia» ${ }^{11}$. Si las pruebas realizadas a los huesos de la ocupación más reciente de estas necrópolis dieran dataciones de los siglos XII y XIII, quedaría definitivamente demostrada la permanencia del grupo mudéjar en la ciudad. Lo que sí parece seguro es que no hay grandes cambios morfológicos o genéticos en la población toledana desde el siglo viI al XI, no observándose restos de componente de población africana subsahariana, bereber o negroide, lo que

9 El-Cheikh, Nadia Maria. "Mourning and the Role of the Nä'iha». En Puente, Cristina de la (ed.). Identidades marginales. Estudios onomásticos-biográficos de Al-Andalus, XIII. Madrid: Consejo Superior de Investigaciones Científicas, 2003, pp. 395-412; ÍDEM. "The gendering of 'death' in Kitāb al 'iqd al-farīd». Al-Qantara, 2010, vol. XXXI, n. ${ }^{\circ} 2$, pp. 411-436; Halevi, Muhammad's grave, p. 114.

10 Aвboud-Haggar, El tratado jurídico, vol. II, pp. 174-175 (fols. 179v-180r del tratado).

11 Así lo proclaman algunos de los artículos más recientes, como Ruiz TABOADA, Arturo. «Comments on Muslim, Jewish and Christian burial practices in medieval Toledo (Spain)». Journal of Islamic Archaeology, 2015, vol. 2, n. ${ }^{\circ}$ 1, pp. 51-71; e ÍDEM. "El límite sur de la necrópolis medieval judía del Cerro de la Horca y el problema del contacto con otros cementerios». Sefarad, 2016, vol. 76, n. o 1, pp. 121-157. Los hallazgos han hecho que trabajos más antiguos, como los de Delgado Valero, Clara. «El cementerio musulmán de Toledo». En Simposio Toledo Hispanoárabe. Toledo: Univesidad de Castilla-La Mancha, 1986, pp. 187-191; e ÍDEm. "Arqueología islámica en la ciudad de Toledo». En Actas del Primer Congreso de Arqueología de la provincia de Toledo. Toledo: Diputación Provincial de Toledo, 1990, pp. 407-432, hayan quedado obsoletos; no así sus estudios de las lápidas. 
permite pensar en una continuidad de la población autóctona o cristiana andalusí, que se iría convirtiendo paulatinamente ${ }^{12}$.

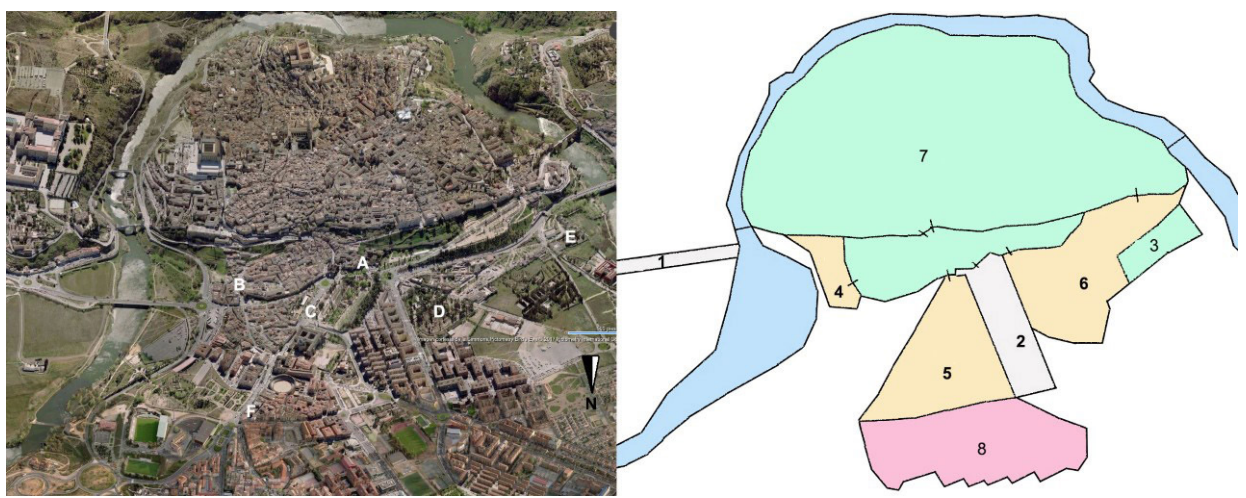

Figura 1. Plano de Toledo y sus cementerios, según Ruiz Taboada, Arturo. «La gestión de los cementerios históricos en el marco del planeamiento contemporáneo: la necrópolis judía de Toledo». Miscelánea de Estudios Árabes y Hebraicos. Sección de Hebreo, 2019, vol. 68, p. 66.

Con permiso del autor.

Leyenda: A, puerta Antigua de Bisagra; B, puerta del Vado; C, camino de Madrid; D, Circo Romano;

E, iglesia de Santa Leocadia. 1, camino a Córdoba y necrópolis romana del paseo de la Rosa; 2 , necrópolis romana de la avenida de la Reconquista; 3 , necrópolis romana y cementerio medieval cristiano de Santa Leocadia; 4, cementerio musulmán de la puerta del Vado; 5, cementerio musulmán

del camino de Madrid; 6, cementerio musulmán del Circo Romano; 7, cementerios cristianos intramuros; 8, necrópolis judía del cerro de la Horca.

Como es bien sabido, los límites naturales de la ciudad de Toledo condicionan de manera importante la selección de un lugar de enterramiento una vez que se produce el traslado de la ciudad al meandro del río, en vez de la ocupación más abierta de la vega, al término del periodo visigodo ${ }^{13}$. La necrópolis tardorromana más extensa estaba junto a Santa Leocadia, y debió permanecer activa durante el periodo visigodo, hasta el abandono de la zona por los cristianos, debido a la inestabilidad causada por las frecuentes revueltas toledanas ${ }^{14}$. Mientras que los cristianos podían mantener sus enterramientos

12 Molero Rodrigo, Isabel. Estudio bioantropológico de la Maqbara andalusí de Toledo (Siglos VIIIXI). Apuntes sobre el proceso de islamización. Madrid: Universidad Autónoma, 2017, tesis doctoral inédita, pp. 185-186.

13 Ruiz Taboada, «Comments», pp. 53-54; De Juan García, Antonio. "Los cementerios islámicos de Toledo en la Edad Media». En Pacheco Jiménez, César (ed.). La muerte en el tiempo. Arqueología e historia del hecho funerario en la provincia de Toledo. Talavera de la Reina: Colectivo de Investigación Histórica Arrabal, 2016, pp. 265-291: p. 270 (ed. CD). Este último trabajo supone una actualización de los previos realizados por el mismo autor.

14 Carrobles Santos, Jesús. "Toledo 284-546. Los orígenes de la capitalidad visigoda». En Regia sedes toletana. La topografía de la ciudad de Toledo en la tardia Antigüedad y Alta Edad Media. Toledo: Diputación de Toledo, 2007, pp. 45-92: p. 63. Barroso Cabrera, Rafael y Morín de Pablos, Jorge. Regia Sedes Toletana. El Toledo visigodo a través de su escultura monumental. Toledo: Diputación de Toledo, 2007, pp. 
dentro o en las inmediaciones de las principales iglesias durante el periodo emiral, los primeros musulmanes que se instalaron en la ciudad debieron buscar un lugar apropiado, alejado de los cementerios cristianos y que cumpliera con sus propios requisitos. Dado lo dificultoso de la islamización de la ciudad y la resistencia cristiana en ella, es lógico que no aparezcan altas concentraciones de tumbas de ritual islámico hasta entrado el siglo IX, como señalan los especialistas ${ }^{15}$. Estas se encontrarían en tres zonas diferentes: el cementerio de los arrabales de Bāb al-Saqra (la Vieja Puerta de la Bisagra) ${ }^{16}$, situado en y alrededor del circo romano, separadas del río por un muro de contención; el cementerio de la Bāb al-Mahada (Puerta del Vado), en la cerca del arrabal; y uno en la Vega Baja, cerca de la ermita del Cristo de la Vega, antiguamente Santa Leocadia "de Afuera», en antiguas zonas de habitación visigoda. Se trata de fosas simples, «en alcaén», excavadas en el mismo suelo ${ }^{17}$, la tipología más antigua, y las del Circo concretamente se han datado por radiocarbono entre 664-770 y 863-984, es decir, en pleno periodo emiral y califal ${ }^{18}$. Las inhumaciones en decúbito lateral derecho, orientadas en un eje SW-NE, presentan cubiertas de distintos tipos (tejas, piedras, ladrillos y tejas combinadas, etc.) o bien sin cubrición alguna $^{19}$. La gran extensión del cementerio, desde la antigua basílica de Santa Leocadia, a orillas del Tajo, hasta la ermita de San Eugenio, y luego hasta el Circo y por el norte hasta el Cerro de la Horca, ha hecho pensar en la existencia de varios cementerios, pero también puede ser que se deba a momentos de expansión de uno solo en varias fases marcadas por la creciente importancia de la ciudad en la política califal y de Taifas, y por la superpoblación dentro del recinto urbano, que obligó a la reutilización de algunas tumbas, incluso de rito musulmán ${ }^{20}$. Las excavaciones de 2013 revelaron además el muro

751-755, mencionan varias lápidas procedentes de la zona que se extiende hacia San Pedro el Verde; RuIz TABOADA, Arturo. La vida futura es para los devotos. La muerte en el Toledo medieval. Madrid: Ediciones de La Ergástula, 2013, pp. 19-20. Sobre el periodo de inestabilidad, Manzano Moreno, Eduardo. Conquistadores, emires y califas. Barcelona: Editorial Crítica, 2006, pp. 317-329.

15 De Juan García, «Los cementerios islámicos», p. 282.

16 Para las fuentes árabes que lo citan, véase De JuAN GARCía, «Los cementerios islámicos», pp. 270271.

17 Ruiz Taboada, Arturo. «La necrópolis medieval del Cerro de la Horca de Toledo». Sefarad, 2009, vol. 69, n. ${ }^{\circ}$ 1, pp. 25-41, concretamente p. 29.

18 De Juan García, Antonio. Enterramientos musulmanes del circo romano de Toledo. Toledo: Consejería de Educación y Cultura, 1987; De Juan García, Antonio; Sáinz Pascual, M. ${ }^{a}$ Jesús y SánchezPalencia Ramos, Francisco Javier. «Excavación de urgencia en el cementerio islámico del circo romano de Toledo». En I Congreso de Historia de Castilla-La Mancha. Toledo: Junta de Comunidades de Castilla-La Mancha, 1988, vol. V, pp. 43-49; ÍDEM, «Los cementerios islámicos», pp. 277-279, para un listado de todas las intervenciones realizadas hasta el momento. Véase también RuIz TABOADA, «Comments», pp. 57-58; Ruiz TABOADA, La vida futura, p. 47, fecha la excavación junto a Santa Eulalia en el siglo x. También MoleRo RodRIGO, Estudio bioantropológico, pp. 38-44, siguiendo al anterior.

19 Maquedano Carrasco, Bienvenido; Rojas Rodríguez, Juan Manuel y Sánchez Peláez, Elena I. «Nuevas aportaciones al conocimiento de las necrópolis medievales de la Vega Baja de Toledo (I)». Tulaytula. Revista de la Asociación de Amigos del Toledo Islámico, 2002, n.o 9, pp. 19-53.

20 Esta amplitud no debería sorprendernos, pues es común a las demás grandes urbes del periodo islámico en la Península, como Córdoba, Sevilla, Málaga o Zaragoza. Recordemos que Toledo es la gran capital de la Marca Media. RuIz TABOADA, La vida futura, pp. 21-23. En el caso islámico, bastaba con apilar 
ENTERRAMIENTOS Y RITOS FUNERARIOS ISLÁMICOS:

DE LO ANDALUSí A LO MUDÉJAR A TRAVÉS DEL CASO TOLEDANO

ANA ECHEVARRÍA

$\mathrm{SW}^{21}$. La orientación de las entradas a la ciudad desde el centro del califato, la principal por el puente de Alcántara, y la fluvial desde la Marca Superior por la vía del Tajo, situada sin duda en la zona del Vado, hace que la mayor concentración de necrópolis quedara alejada de la visión y el acceso de los viajeros que entraban en la urbe.

A estos cementerios se añade otro más, documentado por Rodrigo Amador de los Ríos durante sus trabajos en la ciudad, y datado por él más concretamente durante el periodo de Taifas, ubicado al norte de la ciudad, entre el hospital de San Juan Bautista y la ermita de San Eugenio, a ambos lados del antiguo camino de Madrid y cerca de la puerta de Bisagra nueva ${ }^{22}$. Este cementerio, al contrario que los demás, se caracteriza por utilizar cipos realizados en distintas variedades de piedra, bien formados por acumulaciones de piedras o bien en forma de columna exenta en la cabecera de la tumba, que varía en tamaño y altura, y puede presentar inscripciones en caracteres cúficos. De antecedentes helenísticos, durante el periodo islámico aparecen en Qayrawan (Túnez) hacia el 862, y no hay indicios de su utilización en al-Andalus hasta el periodo taifa, a principios del siglo XI, más concretamente en el Toledo de los Banū Dhi'l-Nūn ${ }^{23}$. La utilización de esta tipología de marcador difiere de las lápidas planas que se utilizaban en los periodos emiral y califal, hasta el punto de que en Córdoba no se ha hallado por el momento ningún cipo funerario ${ }^{24}$. Pero sí aparecen cipos en necrópolis egipcias del Delta y en Alejandría, en Nápoles y en Sicilia ${ }^{25}$. La variedad de materiales utilizados para tallar el cipo, que solía tener un acabado sencillo, variaba según la disponibilidad de piedra local, o la posibilidad de importarla: mientras que en Ávila a partir del siglo XII

los huesos más antiguos -o ni siquiera- y cubrir de nuevo el terreno con tierra para cumplir el precepto de descansar sobre el suelo. Véase EchevarRía, Ana. «Islamic Confraternities and Funerary Practices: Hallmarks of Mudejar Identity in the Iberian Peninsula?». Al-Masaq: Islam and the Medieval Mediterranean, 2013, vol. 25, n. ${ }^{\circ}$, pp. 345-368, especialmente p. 359.

21 Ruiz Taboada, "Comments», p. 57. El análisis de los restos óseos de esta campaña ha sido realizado por Molero Rodrigo, Estudio bioantropológico, pp. 45-180.

22 AMADOR DE LOS Ríos, Rodrigo. Excavaciones en Toledo: memoria de los resultados obtenidos en las exploraciones y excavaciones practicadas en el año 1916. Madrid: Tip. de la Revista de Archivos, Bibliotecas y Museos, 1917, pp. 6-36, recogido en Ruiz TABOADA, La vida futura, pp. 57-59.

23. Delgado Valero, Clara. Materiales para el estudio morfológico y ornamental del arte islámico en Toledo. Toledo: Consejería de Educación y Cultura, 1987, pp. 23-27; Martínez NúNEz, María Antonia. «Epigrafía funeraria en al-Andalus (siglos IX-XII)». Mélanges de la Casa de Velázquez, 2011, vol. 41, n. ${ }^{\circ}$ 1, pp. 181-209, concretamente pp. 194-196. La aparición de un cipo similar en Calatrava la Vieja no desdice esta datación. Sobre la denominación del cipo en árabe, véase JIMÉNEZ GADEA, «Estelas funerarias», pp. 223-224.

24 León Muñoz, Alberto. “"iHombres! la promesa de Dios es verdadera”... El mundo funerario islámico en Córdoba (siglos viII-XIII)». Arqueología Medieval, 2008-2009, vol. 4-5, pp. 24-49: p. 45.

25 Delgado Valero, Clara. «El arte de Ifrīqiya y sus relaciones con distintos ámbitos del Mediterráneo: al-Andalus, Egipto y Sicilia». Al-Qantara, 1996, vol. 17, n.o 2, pp. 291-319, especialmente pp. 292-293. La relación entre los cipos y la reutilización de fustes de columnas de ruinas romanas precedentes en las tumbas de algunos jeques en Siria ha sido puesta de manifiesto por GonnelLA, Julia. «Columns and Hieroglyphs: Magic Spolia in Medieval Islamic Architecture of Northern Syria». Muqarnas, 2010, vol. 27, pp. 103-120, concretamente pp. 111-113. Sería interesante analizar la posible procedencia del material toledano de monumentos tardorromanos precedentes, evidentemente disponibles en los alrededores, y que facilitarían el trabajo de los escultores. 
son casi exclusivamente en granito, en Toledo se utiliza el mármol blanco ${ }^{26}$. La epigrafía de estos cipos y de los ladrillos funerarios que han aparecido asociados a las tumbas, con epigrafía árabe, ha sido analizada por varios autores, sobre todo Lévi Provençal, Delgado Valero y Martínez Núñez ${ }^{27}$, e incluye, aparte de la mención del nombre del difunto, inscripciones coránicas que se han relacionado con la recitación o lectura de estas en las visitas a los cementerios por parte de los parientes del difunto, a manera de plegarias de intercesión ${ }^{28}$. Dado que la mayoría de los cipos estudiados pertenecen a personajes de la aristocracia de la ciudad, podemos suponer que todavía queda por descubrir la rauda de los reyes de Taifas, probablemente situada dentro del recinto de los alcázares (vid. figura 2).

Al cambio de indicadores de las tumbas habría que añadir, según Molero Rodrigo, una ligera modificación también en el ritual de las inhumaciones, que se modifican en el cementerio Taifa respecto a los enterramientos anteriores del Circo de la etapa entre los siglos VIII-X. Se trata de la forma de flexionar las piernas para conseguir equilibrar el cuerpo en decúbito lateral, pues, mientras que los musulmanes más antiguos se encuentran en decúbito lateral estricto, con las extremidades bien flexionadas, los del periodo taifa se encuentran en decúbito lateral derecho con extremidades ligeramente flexionadas. A pesar de haberse realizado las pruebas en un número determinado de casos, sería la primera vez en la que se constata antropológicamente un cambio de ritual funerario dentro de una misma comunidad a lo largo del tiempo ${ }^{29}$.

26 Martínez NúÑEZ, «Epigrafía funeraria», p. 194; Jiménez GadeA, Javier y Villanueva ZubiZARreta, Olatz. «Elementos decorativos góticos en lo mudéjar abulense: las estelas funerarias». En Alonso Ruiz, Begońa (ed.). La Arquitectura Tardogótica castellana entre Europa y América. Madrid: Sílex, 2011, pp. 377-388: p. 381; Jiménez Gadea, Javier; Echevarría Arsuaga, Ana; Tapia Sánchez, Serafín de y Villanueva Zubizarreta, Olatz. La memoria de Alá. Mudéjares y moriscos de Ávila. Valladolid: Castilla Ediciones, 2011, pp. 40-43.

${ }_{27}$ LÉvi-Provençal, Évariste. Inscriptions arabes d'Espagne. Paris: Larose, 1931, p. 71, n.o 65, pl. 17c; SÁnchez Llorente, Margarita. «Memorial stone». En Museum with No Frontiers. Discover Islamic Art. http://www.museumwnf.org/thematicgallery [última consulta: 23/9/2019]; MARTínez NúŃEZ, «Epigrafía funeraria», pp. 195-196; Delgado Valero, Materiales, pp. 93-131.

28 Halevi, Muhammad's grave, pp. 28-29. Las azoras Ya'Sin (XXXVI), al-Baqara (II) y al-Mulk (LXVII) solían recitarse durante la visita del cuadragésimo día después del funeral o en las visitas al cementerio de los viernes. La segunda azora también aparece en las inscripciones coránicas de Mértola en el siglo XII. Macias, Santiago. Mértola. Le dernier port de la Méditerranée: Catalogue de l'exposition "Mértola-Histoire et Patrimoine (Ve-XIIT siècles)». Mértola: Campo Arqueológico de Mértola, 2006, vol. III, p. 47. Otra inscripción abulense recoge la azora XXVIII, 88: JIMÉNEZ GADEA, «Estelas funerarias», p. 243. En la inscripción del visir Abū 'Umar Mūsà, reutilizada por el judío Meir (MAN inv. 57478), aparecen las azoras XXXV, 5; III, 1-4 y XLVIII, 1-4, según RuIz TABOADA, La vida futura, pp. 58-59.

29 Molero Rodrigo, Estudio bioantropológico, pp. 182-183. 


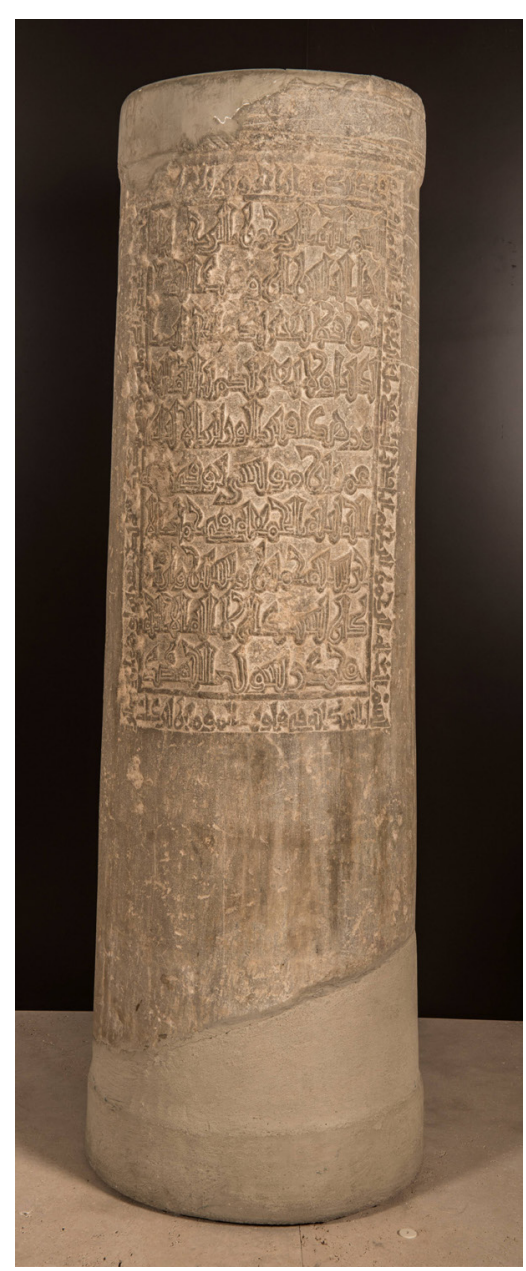

Figura 2. Cipo funerario del visir Abu Umar Musà. Toledo, Museo Arqueológico Nacional. (Inv. 57478. Foto: Ángel Martínez Levas).

3 De CEMENTERIO ANDAlusí A CEMENTERIO MUdÉJAR: ¿CONTINUIDAd DE LOS ESPACIOS FUNERARIOS?

Desgraciadamente, no se conserva el texto literal de los tratados que estipulaban las condiciones que se establecieron en la conquista de Toledo, que marcarán las pautas de lo que sería el marco legal de los musulmanes sometidos mediante pactos hasta la conquista 
de Granada. Su ocupación, el 25 de mayo de 1085, supuso la anexión del amplio territorio de la taifa toledana y su área de influencia en Valencia y Badajoz, así como la culminación del ideal de «reencuentro» de la monarquía leonesa con su pasado visigodo. Las crónicas medievales que transmiten la conquista no mencionan detenidamente los edificios y el cementerio de la comunidad hasta el episodio de la ocupación de la mezquita aljama ${ }^{30}$. Los musulmanes en un principio exigían mantener su mezquita aljama en el centro de la ciudad. La consagración como catedral de la mezquita aljama de Toledo, que en teoría debería haberles sido respetada, supuso la ruptura de las capitulaciones y fue un ejemplo de lo que sucedería en el futuro en otras capitales. Para evitar conflictos, en las siguientes capitulaciones lo que se firmaría sería un plazo de un año para que los cristianos pudiesen ocuparla ${ }^{31}$.

Es bien conocido el rechazo de varios estudiosos a la presencia de mudéjares en Toledo después de la conquista ${ }^{32}$. Sin embargo, la evidencia documental muestra que hubo cierto número de musulmanes toledanos que, o bien permanecieron, o bien regresaron poco después de su partida; nada lo impedía, pues Alfonso VI sólo se obligó a permitir la emigración de todos aquellos que lo deseasen y a que, si alguno volvía después de su marcha, se aposentaría en Toledo con la hacienda que tuviese sin ninguna objeción,

30 Ibn 'ID̄ĀRì AL-Marrakushī. La caída del califato de Córdoba y los reyes de Taifas (al-Bayân alMugrib), ed. F. Maíllo Salgado. Salamanca: Ediciones Universidad de Salamanca, 1993, pp. 232-234, relata el enfrentamiento de Fernando I con los habitantes de Toledo. Para la conquista, Ibn Al-Kardabus. Historia de al-Andalus, ed. F. Maíllo Salgado. Madrid: Akal, 1986, p. 105; Primera crónica general de España, ed. R. Menéndez Pidal y D. Catalán. Madrid: Atlas, 1977, pp. 538-539. Comentados con más amplitud en EcHevarría Arsuaga, Ana. "Desplazamientos de población y movilidad social en los inicios del mudejarismo castellano». Actas del XI Congreso de Estudios Medievales. Ávila-León: Fundación Sánchez-Albornoz, 2009 , pp. 499-520, concretamente p. 505.

31 Según Ibn Bassām al-Santarīn̄. Menéndez Pidal, Ramón y García Gómez, Emilio. «El conde mozárabe Sisnando Davídiz y la política de Alfonso VI con los Taifas». Al-Andalus, 1947, vol. XII, n. ${ }^{\circ}$ 1, pp. 27-41; para una traducción más moderna, ver EcKer, Heather L. "Administradores mozárabes en Sevilla después de la conquista». En Sevilla 1248. Congreso Internacional Conmemorativo de la Conquista de la Ciudad de Sevilla por Fernando III. Madrid: Centro de Estudios Ramón Areces, 2000, pp. 821-838, concretamente p. 823 .

32 MolénAt, Jean-Pierre. «Tolède à la fin du XI ${ }^{\mathrm{e}}$ siècle et au début du XII ${ }^{\mathrm{e}}$ : le problème de l'émigration ou de la permanence des musulmans». En Laliena Corbera, Carlos y Utrilla Utrilla, Juan F. (coords.). De Toledo a Huesca. Sociedades medievales en transición a finales del siglo XI (1080-1100). Zaragoza: Institución Fernando el Católico, 1998, pp. 101-111; ÍDEM. «Les mudéjars de Tolède: professions et localisations urbaines». En VI Simposio Internacional de Mudejarismo. Actas. Teruel: Instituto de Estudios Turolenses, 1995, pp. 429-435: p. 430. Redunda en la misma idea en Campagnes et monts de Tolède du XII au XV́ siècle. Madrid: Casa de Velázquez, 1997, pp. 27-41. También le sigue O’Callaghan, Joseph F. "The Mudejars of Castile and Portugal in the Twelfth and Thirteenth Centuries». En Powell, James M. (ed.). Muslims under Latin Rule (1100-1300). Princeton: Princeton University Press, 1990, pp. 11-56, concretamente pp. 26-27. Esta teoría es aceptada por numerosos autores, y debatida por otros, especialmente el retorno de grupos de musulmanes a sus lugares de origen, bibliografía en MolénAT, Jean-Pierre. «Les sources chrétiennes sur l'histoire des 'musulmans soumis' dans la Péninsule Ibérique médiévale». En Sidarus, Adel (ed.). Fontes da História de al-Andalus e do Gharb. Lisboa: Centro de Estudos Africanos e Asiáticos, 2000, p. 162. Buresi, Pascal. La frontière entre chrétienté et Islam dans la Péninsule Ibérique. Du Tage à la Sierra Morena (fin XI'-milieu XIII siècle). Paris: Publibook, 2004, pp. 74-82. 
ENTERRAMIENTOS Y RITOS FUNERARIOS ISLÁMICOS:

DE LO ANDALUSí A LO MUDÉJAR A TRAVÉS DEL CASO TOLEDANO

ANA ECHEVARRÍA

seguramente una vez que las mejores tierras y viviendas fueran repartidas entre los cristianos $^{33}$. Entre ellos, quedarían tres juristas, de los entre cinco y ocho que se documentan en la ciudad antes del asedio, a cargo de la comunidad ${ }^{34}$.

Podemos suponer que, si la aljama de Toledo persistió, lo harían también sus áreas de enterramiento, aunque fueran reducidas, pues no obstaculizaban la presencia cristiana, que contaba con otros lugares para su inhumación ${ }^{35}$. Cuando Toledo fue conquistada por los cristianos en 1085, los mudéjares continuaron recibiendo sepultura a extramuros de la ciudad. Las únicas menciones a espacios funerarios mudéjares como tales se localizan a extramuros en el barrio de Santiago (zona de la Puerta de Bisagra), en el área de Santa Leocadia, San Eugenio y San Antón. La disminución de la población supondría una retracción del área del cementerio, por lo que es lógico que este no se trasladara. Asimismo, la sustitución de la mezquita mayor por otras más pequeñas (San Salvador, que funcionó como mezquita aljama hasta 1159, y la del vecindario de Bāb al-Mardūm hasta 1186, en que fue cedida a la Orden de San Juan ${ }^{36}$ supondría una alteración de las rutas de las comitivas funerarias. La mezquita de El Salvador estaba relativamente bien orientada para salir de la ciudad por la puerta del Cambrón, si la plegaria funeraria se hacía en su recinto -como era acostumbrado en algunas ocasiones-, mientras que la de Bāb al-Mardūm tenía su propia salida para tomar el camino que conduciría hacia Santa Eulalia y su cementerio.

La permanencia de la comunidad mudéjar dentro y en los alrededores de la ciudad es confirmada por la reforma de la jurisdicción criminal en caso de asesinato realizada por Alfonso VII en el fuero de Toledo de 1118, en el que confirmaba todos juntos los fueros dados separadamente a castellanos, mozárabes y francos por Alfonso VI. El documento, que modificaba también la situación acordada en los pactos a este respecto con 105.

33 Para el compromiso de Alfonso solo queda recurrir a IBN Al-Kardabus, Historia de al-Andalus, p.

34 Marín, Manuela. "Des migrations forcées: les 'ulama' d'Al-Andalus face à la conquête chrétienne». En Наммам, M. (ed.). L'Occident musulman et l'Occident chrétien au Moyen Âge. Rabat: Publications de la Faculté des Letres et des Sciences Humaines, 1995, pp. 43-59: especialmente pp. 45-47, utiliza varios diccionarios biográficos para identificar a cinco ulemas en la ciudad en ese momento. Además de los dos mencionados por Ibn Mutahir y transmitidos por el Kitāb al-Silā’ de Ibn Baškuwāl, (cit. MolÉNAT, «Tolède à la fin», p. 105) Abu Ŷa'far Aḥmad ibn 'Abd al-Rahmān ibn Mutāhir al-Anșārī (m. 1095-1096) y Abū Bakr Muḥammad ibn Muḥammad ibn 'Abd al-Rahmān ibn Ŷamāhir al-Haŷrī se quedó Abū 1-Qāsim ibn al-Jayyāt, un asceta que finalmente se convirtió al cristianismo y escribió a al-Mu'tamid de Sevilla (10271095) de parte de Alfonso VI. Otros dos ulemas abandonaron la ciudad en vísperas de la conquista. Ocho jurisconsultos más son mencionados por la famosa Takmila de Ibn al-'Abbār, diciendo que emigraron de la Taifa de Toledo, pero sin dar una razón específica para ello, aunque podemos suponer que la conquista de este territorio fue la causante. Echevarría Arsuaga, «Desplazamientos», p. 506.

35 Ruiz Taboada, «Comments», p. 53.

36 Porres Martín-Cleto, Julio. «La mezquita toledana del Solarejo, llamada de las Tornerías». AlQantara, 1983, vol. IV, pp. 411-421, sostiene que la del Salvador estuvo activa hasta 1159, mientras que la del Solarejo la reemplazaría a partir de esa fecha. Sobre ello véase también García Sánchez de Pedro, Julián y Corral Vacheron, Isabelle. "La segunda al-ŷami 'de Tulaytula: la mezquita de El Salvador». En Mezquitas en Toledo, a la luz de los nuevos descubrimientos. Toledo: Consorcio de la Ciudad de Toledo, 2006, pp. 233259: p. 235. Sobre estas mezquitas, véase el artículo de Susana Calvo en este monográfico. 
los musulmanes, estaba firmado por varios musulmanes, posiblemente autoridades de aljamas de la órbita toledana ${ }^{37}$.

$\mathrm{Si}$ aceptamos los datos sobre población mudéjar toledana que aparecen en los documentos publicados por González Palencia ${ }^{38}$, a lo largo de la centuria siguiente a la conquista se observa una transferencia de la población musulmana desde el centro de la ciudad y los alrededores de la misma, incluyendo sus aldeas y alquerías, hacia áreas más lejanas, pero no necesariamente a territorio islámico. Mientras tanto, tenían lugar cambios en las tendencias inversoras y las ocupaciones profesionales de los musulmanes. Hacia 1092 se había hecho un primer repartimiento, sin trazas de forma escrita como los posteriores $^{39}$. La administración de los bienes de la catedral, que incluían todas las propiedades antańo pertenecientes a la mezquita mayor, combinadas con las nuevas tierras y fortalezas destinadas a mantener la defensa del recientemente creado arzobispado primado de Castilla (diciembre de 1086), así como los numerosos monasterios fundados en la ciudad, constituía un enorme esfuerzo poblacional para la Iglesia, que debía asegurarse de tener suficientes hombres para hacer productivas las tierras ${ }^{40}$. De la misma forma, la actividad agrícola en las almunias, huertos y viñedos que correspondieron a Alfonso VI además del uso del alcázar y la almunia real situada junto al puente de Alcántara de Toledo, obligaba a mantener oficios desempeñados por musulmanes experimentados en sistemas de irrigación y el mantenimiento de las construcciones, y por lo tanto su permanencia debía quedar garantizada. Se observa una lenta tendencia a la venta de propiedades para obtener dinero contante y sonante, una emigración gradual hacia afuera de las murallas y una posterior vuelta a las casas que quedaron desocupadas por los cristianos, o bien a inmuebles tomados a censo a los miembros del cabildo o de otras fundaciones

37 'Ali ibn Jayr en Madrid, Sulayman ibn Hazm en Alfamín, Jalif al-Qatal y 'Abd al-Rahman ibn 'Abd al-Rahman en Talavera o Galib ibn 'Abd al-Aziz en Maqueda. Muñoz y Romero, Tomás. Colección de fueros municipales y cartas pueblas. Madrid: Imprenta de Don José María Alonso, 1847, p. 366; Echevarría Arsuaga, «Desplazamientos», p. 508.

38 González Palencia, Ángel. Los mozárabes de Toledo en los siglos XII y XIII. 4 vols. Madrid: Instituto Valencia de Don Juan, 1926-1930. En Echevarría ArsuagA, «Desplazamientos», pp. 507-508 planteo una forma de distinguir la onomástica árabe de mozárabes y mudéjares toledanos. Estos últimos se caracterizan por utilizar como nisba nombres de afiliación tribal, como Qurayshī o Ansarī; topónimos relacionados con la frontera más reciente - «de Jaén», «de Granada»-, que marcarían el origen de los esclavos traídos a Toledo con motivo de las guerras de conquista que se van manumitiendo posteriormente; o el adjetivo "moro/a» apuesto a un sustantivo, siempre designa el origen musulmán de una persona.

39 González Palencia, Los mozárabes, vol. I, 2, doc. 2, se refiere a varias parcelas de tierras limítrofes dadas al rey y a miembros de la nobleza. Sobre el reparto, GLICK, Thomas F. "Reading the Repartimientos: Modelling Settlement in the Wake of Conquest». En Meyerson, Mark D. \& English, Edward D. (eds.). Christians, Muslims and Jews in Medieval and Early Modern Spain. Interaction and Cultural Change. Notre Dame: University of Notre Dame Press, 2000, pp. 20-39, concretamente pp. 24-25. Echevarría, Desplazamientos, p. 507.

40 García Luján, José Antonio. Privilegios reales de la Catedral de Toledo (1086-1462). Formación del patrimonio de la S.I.C.P. a través de las donaciones reales. Toledo: Caja de Ahorros Provincial de Toledo, 1982, vol. II, p. 18, doc. 1. En las propiedades monásticas, especialmente en las femeninas, es frecuente encontrar contratos que estipulan la manumisión de esclavos musulmanes en un plazo de cinco años a cambio de su trabajo en las tierras del monasterio. GonzÁlez Palencia, Los mozárabes, vol. I, docs. 7 y 380; vol. III, doc. 787, de mayo de 1235 . 
ENTERRAMIENTOS Y RITOS FUNERARIOS ISLÁMICOS:

DE LO ANDALUSÍ A LO MUDÉJAR A TRAVÉS DEL CASO TOLEDANO

ANA ECHEVARRÍA

religiosas recién establecidas en la ciudad. En la vega del Tajo, la política fue más tajante en algunas poblaciones como Oreja y Coria, que debían asegurar la frontera contra almorávides, primero, y almohades, más tarde ${ }^{41}$.

Los mudéjares toledanos ya parecen estar medianamente organizados en esa época, a juzgar por los datos proporcionados por la documentación en lengua árabe procedente del archivo de la catedral. En la ciudad vivieron durante el siglo XII el jeque Aben Mosquiq, el alfaquí Abenlahacer, el almotacén Jazim, e incluso, un poco más tarde (1210), un sufí llamado Galib. Igualmente, la presencia de ulemas en Toledo continuó con la llegada de cautivos durante las campañas andaluzas: Fạ̣l ibn Muhammad ibn 'Abd al-Azīz ibn Samāk al-Mu'āfirī de Sevilla e Ibn al-Saffār de Córdoba permanecieron en la ciudad tras recuperar su libertad, enseñando allí y estableciendo vínculos familiares que llevan a pensar que la ciudad castellana contaba ya con una comunidad mudéjar en la época, protegida por los reyes y por el propio arzobispo ${ }^{42}$. Ello explicaría por qué, al terminar el siglo XIII, Toledo aparece en la relación de «morerías de los obispados» que figuran en los libros de cuentas y gastos de Juan Mateo de Luna, camarero mayor de la frontera de Sancho IV de Castilla para 1293-1294, cuando recaudaba el castellano de oro para la guerra contra los benimerines ${ }^{43}$.

Lo que sí había sucedido era la transformación de la mezquita en iglesia de San Salvador, con su consiguiente sustitución por la que sería la última de las mezquitas mudéjares de la ciudad, la del Solarejo (en referencia a la plaza trasera a la que salía su puerta y su jardín) o Tornerías, llamada por los musulmanes la yami al-Wadi 'a, que podría traducirse como "mezquita de la Encomienda» ${ }^{44}$. Esta se encontraba en el barrio comercial de Zocodover, junto a los negocios de artesanía y venta, en la confluencia entre las calles de los herreros y los zapateros. La vivienda mudéjar se concentraba en dos barrios: el de san Isidoro (barrio de los alfareros), donde se encontraba su carnicería, y el barrio conocido como de Sancho Minaya, donde habitaban los musulmanes de buena posición, aunque consta que ya habían vendido sus casas hacia la segunda mitad del xv. Toda esta zona fue

41 En Oreja, perteneciente a la Orden de Santiago, el fuero (1139) menciona expresamente la expulsión de los moros de la villa. O'Callaghan, "The Mudejars of Castile», p. 14. Martín Rodríguez, José Luis. Orígenes de la Orden Militar de Santiago (1170-1195). Barcelona: Consejo Superior de Investigaciones Científicas, 1974 , pp. 178-180, doc. 8.

42 González Palencia, Los mozárabes, vol. I, pp. 151-152 y 233-241; cit. Buresi, La frontière, p. 75.

43 Las demás morerías organizadas por obispados eran las de Palencia, Plasencia, Cuenca, Ávila, Segovia y las de la Transierra del reino de León. López Dapena, Asunción. Cuentas y gastos (1292-1294) del rey D. Sancho IV el Bravo (1284-1295). Córdoba: Monte de Piedad y Caja de Ahorros de Córdoba, 1984, pp. 197-199 y 636-637. Echevarría Arsuaga, Ana. "La "mayoría” mudéjar en León y Castilla: legislación real y distribución de la población (siglos XI-XIII)». En la España Medieval, 2006, vol. 29, pp. 7-30, concretamente pp. 20 y 28-30; e ÍDEM. «La política respecto al musulmán sometido y las limitaciones prácticas de la cruzada en tiempos de Fernando III (1199-1252)». En Ayala Martínez, Carlos de y Ríos Saloma, Martín F. (eds.). Fernando III, tiempo de cruzada. Madrid: Sílex, 2012, pp. 383-414: pp. 384-385.

44 Sobre esta mezquita, véase Delgado Valero, «La estructura urbana», pp. 83-84; Porres MarTín-Cleto, Julio. «¿Restos de una mezquita toledana?». Al-Andalus, 1978, vol. XLIII, n. ${ }^{\circ}$ 2, pp. 457-459; e ÍdEM, «La mezquita toledana», pp. 411-421; Mayor, Rafael y Echevarría Arsuaga, Ana. "Hermanos y cofrades en la aljama de Toledo a principios del siglo Xv». Anaquel de Estudios Árabes, 2015, vol. 26, pp. 163185: p. 174. 
enterrada bajo sucesivas ampliaciones de la catedral ${ }^{45}$. El hecho de que Toledo contara con una única mezquita conocida, de escaso tamaño, con un pozo en su planta baja y unas tiendas que servían para su mantenimiento, no debe llevarnos a pensar que la comunidad mudéjar de la ciudad fuera muy reducida, pues contaba en el siglo XV con unas 100 cabezas de familia ${ }^{46}$. La población total, que ascendería a unas 500-700 personas según la ratio por hogar, necesitó ampliar el área de su cementerio, como prueba el que a partir del siglo XIII se encuentren enterramientos de nuevo dentro de los límites del recinto del circo romano ${ }^{47}$. Sabemos por un documento de 1341 que Juan Fernández, alcalde mayor de Toledo, vendía en la vega de Toledo tres fanegas de tierra en dos pedazos que lindaban con el «onsario de los moros» y con otra tierra de la ciudad ${ }^{48}$

\section{La REgUlaCión DE LOS ENTERRAMIENTOS MUDÉJARES POR LAS AUTORIDAdeS CRISTIANAS}

Los mudéjares castellanos dispusieron durante todo el tiempo de cementerios separados, correctamente ubicados según las posibilidades de cada villa o ciudad, y mantenidos de acuerdo con las costumbres islámicas. Tanto los pactos firmados como la legislación real hacen mención expresa del permiso otorgado a mudéjares y judíos para tener sus propios cementerios, en los que practicar sus enterramientos siguiendo su propio ritual $^{49}$. Igualmente, la destrucción o violación de cementerios, incluso los de las comunidades minoritarias, estaba severamente castigada en la Partida VII, título 9, ley 12, dado que se encontraban bajo protección real y suponía una violación de los pactos del rey:

E lo que diximos enesta ley ha lugar enlas sepulturas delos cristianos non en las delos enemigos dela fe. \& tal acusac'ion com $<\mathrm{m}>\mathrm{o}$ esta puede fazer cada vno del pueblo qua $<\mathrm{n}>\mathrm{do}$ los parientes del muerto non quisieren fazerla. Otrosi dezimos que los que fizieren alguno delos yerros sobre[+] dichos en sepultura de moro o de iudio del sen $<$ n $>$ orio del rey que puede resc'ebir pena segund aluedrio del iudgador ${ }^{50}$.

Aun así, la capacidad de ambas comunidades para negociar sus espacios funerarios varió según el momento.

45 Passini, Jean. Casas y casas principales urbanas. El espacio doméstico de Toledo a fines de la Edad Media. Toledo: Universidad de Castilla-La Mancha, 2004, p. 117.

46 Mayor y Echevarría Arsuaga, «Hermanos y cofrades», p. 175.

47 De Juan Garcia, «Los cementerios islámicos», p. 283.

48 AMT, AS, Alacena 2. ${ }^{\mathrm{a}}$, Leg. 1, n. ${ }^{\circ} 5$.

49 Este era el caso también en otros lugares donde la existencia de varias comunidades religiosas planteaba el problema de la diversidad de recintos funerarios, como en El Cairo, donde en época mameluca los cementerios musulmanes se encontraban junto a los de las comunidades dhimmíes. Онтолні, Tetsuya. "Cairene Cemeteries as Public Loci in Mamluk Egypt». Mamluk Studies Review, 2006, vol. X, pp. 85-231, concretamente p. 85. El caso toledano en Ruiz TABOADA, «Comments», pp. 53-54.

50 Alfonso X. Las Siete Partidas, ed. I. A. Corfis. Electronic Texts and Concordances of the Madison Corpus of Early Spanish Manuscripts, CD Rom. Madison, 1999. 
ENTERRAMIENTOS Y RITOS FUNERARIOS ISLÁMICOS: DE LO ANDALUSí A LO MUDÉJAR A TRAVÉS DEL CASO TOLEDANO ANA ECHEVARRÍA

Es evidente que, debido al descenso del número de población musulmana en las ciudades conquistadas, disminuirá proporcionalmente la cantidad de espacio funerario necesario para las comunidades mudéjares. Por ejemplo, se ha calculado que en la Sevilla almohade se contaba con dieciséis cementerios, y trece en Córdoba ${ }^{51}$, mientras que en la época mudéjar estas ciudades y otras villas castellanas podían contentarse si existían uno o dos cementerios de rito islámico y otros tantos judíos. Dado que los cementerios islámicos no necesariamente estaban rodeados de muros, no es extraño hallar hornos o casas en sus inmediaciones. Aunque los lugares de habitación mudéjar llegaron a modificarse sustancialmente en algunas villas castellanas a lo largo de la Baja Edad Media, y las mezquitas se trasladaban con ellos, contando con permiso real, los cementerios no solían moverse de sitio por razones evidentes, sino que más bien se expandieron en la misma zona que ya ocupaban, sin duda debido a que ya estaban extramuros y no ocupaban los lugares más cotizados por los cristianos $^{52}$. Además, debían cumplir una serie de requisitos no escritos: se buscaba una visibilidad mínima, normalmente en zonas bajas y discretas, como la vega toledana, y se prefería que estuvieran vallados, de forma que las tumbas se vieran lo menos posible, manteniendo de paso la privacidad de las minorías en sus momentos de duelo o visita. Los cortejos funerarios debían atravesar la ciudad cristiana lo menos posible, especialmente en domingo. Todas estas medidas contribuyeron a separar el espacio funerario dentro de las ciudades, y buscaban evitar la presencia cristiana en rituales de otras religiones, al tiempo que ayudaban a controlar la reunión de grupos grandes de personas pertenecientes a las minorías con la excusa de actos religiosos en el cementerio $^{53}$. A pesar de mantenerse en el mismo lugar, el cementerio mudéjar toledano experimentó una modificación en su visibilidad desde la ciudad debido a la reorientación de las vías de comunicación al tránsito desde el norte en lugar de una comunicación preferente con al-Andalus. Al cobrar importancia el camino de Madrid, el cementerio mudéjar pasó a encontrarse a la derecha, en la vaguada, y por tanto no necesariamente a primera vista, tapado por una serie de nuevas construcciones conventuales que impedían su detección por el viajero que entrara por esta ruta.

Por otra parte, el cementerio constituía el lugar por antonomasia para manifestar la pertenencia a la fe (islámica en este caso), dado que era el momento definitivo en el que el creyente se encontraría con Dios y se mostraría su pertenencia a la umma. Por ello, los mudéjares, que ya procuraban ser ultra-canónicos en las demás manifestaciones religiosas $^{54}$, mantienen en los cementerios todas las costumbres que ya hemos citado para

51 Valor y Gutiérrez (coords.), The Archaeology of Medieval Spain, p. 242.

52 Con la excepción de Valladolid. Villanueva Zubizarreta, Olatz. «Vivir y convivir bajo la señal de la media luna: mudéjares y moriscos en Valladolid». En Regueras Grande, Fernando y SánChez DeL Barrio, Antonio (coords.). Arte mudéjar en la provincia de Valladolid. Valladolid: Diputación Provincial de Valladolid, 2007, pp. 19-33, concretamente, pp. 23-26.

53 Echevarría, Ana. «Funerary Practices in a Multi-Religious Context from the Iberian Peninsula to the Eastern Mediterranean». En Berner, Alexander; Henke, Jan-Marc; Lichtenberger, Achim; MorsTADT, Bärbel \& Riedel, Anne (eds.). Das Mittelmeer und der Tod. Mediterrane Mobilität und Sepulkralkultur. Leiden: Ferdinand Schöningh, 2016, pp. 179-194.

54 Echevarría, Ana. The City of the Three Mosques: Avila and its Muslims in the Middle Ages, trad. C. López Morillas. Wiesbaden: Reichert Verlag, 2011, pp. 104-122; Villanueva Zubizarreta, Olatz. «Los 
la época puramente islámica, antes de la conquista. Las prácticas religiosas relacionadas con los usos funerarios constituyen así un ejemplo, dentro de los muchos posibles, para comprobar que las modificaciones del ritual se mantuvieron en un mínimo, a pesar de las prohibiciones cristianas en cuanto a las expresiones públicas de su $\mathrm{fe}^{55}$. Así, los enterramientos siguen manteniendo la posición en decúbito lateral derecho sistemáticamente, con una corrección respecto a la orientación a La Meca en algunos casos. Sin embargo, las estelas y cipos con inscripciones coránicas son más reducidas en número, sea porque se prefirió otro tipo de decoraciones, o porque los materiales en los que se realizó la inscripción - pintada en muchos casos, o en cerámica- no nos han llegado. Pero también podría tener que ver con el precio de una inscripción tallada en piedra, que haría inviable su encargo por parte de la media de los mudéjares castellanos ${ }^{56}$. Sobre el presunto abandono del árabe por parte de algunos miembros de la comunidad y su incidencia en este aspecto hablaremos más adelante.

\section{Rituales Vinculados CON LA MUERTE SEgúN LAS FUENTES ESCRitaS MUdÉJARes DEL ENTORNO TOLEDANO}

En Toledo, los especialistas han planteado una continuidad del cementerio islámico en la zona de la Puerta de Bisagra y el Circo Romano, basándose en hallazgos arqueológicos. El segundo nivel de la necrópolis del Circo Romano se ha identificado como mudéjar en las excavaciones de 1987-1988, con orientación NW-SW, y cubierta plana, de tejas, o lucillos. En el periodo tardío, además, las tumbas invadieron el muro SW, por lo que es posible pensar en una expansión de sus límites en busca de nuevo espacio ${ }^{57}$. Parte de ellas se superpondrían al nivel emiral de la misma zona. La necesidad de reutilizar tumbas en periodo mudéjar estaba reconocida en los tratados, lo mismo que en el anterior, lo que permitiría a la comunidad mudéjar seguir usando incluso las mismas tumbas que en periodo islámico:

Si neçesidad oviere entierren en una fuesa mas de uno enpues de otro y tierra entre medias. $\mathrm{Y}$ en fuesa que largo tiempo aya pasado (...) A quanto enterrar mas de uno en una fuesa, pues pongan el mas abantallado dellos delante [orientado] a la alquibla ${ }^{58}$.

mudéjares del norte de Castilla en vísperas del bautismo: expresiones religiosas de un Islam que no fue alÁndalus». e-Humanista/Conversos, 2015, vol. 3, pp. 195-209.

55 Echevarría, «Islamic Confraternities», p. 346.

56 Diem, Werner. The Living and the Dead in Islam. Studies in Arabic Epitaphs, 1: Epitaphs as Texts. Wiesbaden: Harrassowitz Verlag, 2004, pp. 273-275; SchölLER, Marco. The Living and the Dead in Islam. Studies in Arabic Epitaphs, 2: Epitaphs in Context. Wiesbaden: Harrassowitz Verlag, 2004, pp. 273-275. A la misma conclusión llega Jiménez Gadea en su estudio de la epigrafía del cementerio mudéjar abulense: JiMÉNEZ GADEA, Javier. «Acerca de cuatro inscripciones abulenses». Cuadernos Abulenses, 2002, vol. 31, pp. 25-71, concretamente 34-35.

57 De Juan Garcia, Los enterramientos musulmanes, pp. 81-82; Ídem, «Los enterramientos», pp. 277-278; RuIZ TABOADA, «Comments», p. 57.

58 YÇa de Segovia, BNM 2076, fol. 29r; Al-Qayrawānī, Compendio, p. 90. 
ENTERRAMIENTOS Y RITOS FUNERARIOS ISLÁMICOS:

DE LO ANDALUSí A LO MUDÉJAR A TRAVÉS DEL CASO TOLEDANO

ANA ECHEVARRÍA

En general, los mudéjares respetaron la prohibición de utilizar estuco, arcilla o ladrillo dentro o encima de la tumba, como en los cementerios contemporáneos de Granada, Valladolid, Murcia, Valencia y Crevillente ${ }^{59}$; de ahí la extrañeza que produce el que en Toledo se hayan atribuido enterramientos de lucillo, similares a los judíos, a la comunidad mudéjar. Igualmente, el cambio de tipos de inhumación dentro de esta área, de decúbito lateral derecho a decúbito supino, lleva a Ruiz Taboada a manifestar sus dudas sobre la adscripción musulmana de varios de los enterramientos de esta última época ${ }^{60}$. Por lo tanto, debemos pensar en una vecindad de los cementerios judío (desde el Circo Romano al Cerro de la Horca) y mudéjar (en torno al Circo Romano y hacia la Vega Baja), a falta de nuevas excavaciones que delimiten mejor el espacio y tengan en cuenta adecuadamente las diferencias de ritual de los diversos grupos que se encontraban en la ciudad en el periodo mudéjar.

De lo que no cabe duda es de la confirmación de la situación del cementerio mudéjar en las fuentes escritas. A falta de investigar su posible mención en los fondos de protocolos notariales de la ciudad, contamos con la noticia del enterramiento de dońa Fátima, rica propietaria de las tiendas del Alcaná de Toledo por donación de Enrique II, esposa de don Lope, alcalde mayor de los moros y madre de dońa Sohora, esposa de Mahomad al-Qaysī, alcalde mayor de la aljama de Toledo y físico del rey, «en el osario de los mudéjares, cerca de la puerta de la Visagra» ${ }^{61}$. Pero ¿cómo se realizaban exactamente estos entierros mudéjares? En los últimos años, el estudio de fuentes en árabe, castellano y aljamiado nos ha permitido conocer mucho más de cerca este aspecto y comprobar una vez más el cuidado puesto en no salirse ni un ápice de lo que se consideraba la ortodoxia más estricta, para garantizarse así la salvación.

Dos son las fuentes principales para analizar los comportamientos funerarios de los musulmanes castellanos durante el siglo xv, que los vinculan además a las prácticas andalusíes anteriores. Por una parte, los tratados legales y religiosos que ni mucho menos quedaron fosilizados, sino que recogen los cambios y modificaciones impuestas por el paso del tiempo, a la vez que la importancia de la muerte y del entierro a la espera del

59 Sobre las fuentes de estas prohibiciones, véase Fierro, «El espacio de los muertos», p. 156; Echevarría, «Islamic Confraternities», pp. 355-358; Peral Bejarano, Carmen. «Excavación y estudio de los cementerios urbanos andalusíes. Estado de la cuestión». En Torres Palomo y Acién Almansa (eds.). Estudios sobre cementerios, pp. 7-10.

60 Ruiz TABOAda, La vida futura, pp. 74-77.

${ }^{61}$ Archivo de la Catedral de Toledo, E.6.A.2.2. Cit. Esténaga Echevarría, Narciso. «Condición social de los mudéjares en Toledo durante la Edad Media». Real Academia de Bellas Artes y Ciencias Históricas de Toledo, 1924, vol. VI, n. ${ }^{\circ}$ 18-19, pp. 5-27, concretamente p. 17. La familia musulmana de dońa Fátima aparecerá más tarde en las actas de la cofradía de la mezquita de Tornerías. Parte de sus hijas se había convertido, lo que originó un pleito que implicó al arzobispo de Toledo don Pedro Tenorio, y gracias al cual conocemos este detalle. Mención a él hace también MolénAt, Jean-Pierre. «L'élite mudéjare de Tolède aux $\mathrm{XIV}^{\mathrm{e}}$ et $\mathrm{XV}^{\mathrm{e}}$ siècle». En Liber largitorius. Études d'histoire médiévale offertes à Pierre Toubert. Genève: Librairie Droz, 2003, pp. 563-577: pp. 572-574, estudiado y editado parcialmente por Ortego Rico, Pablo. «Las mujeres mudéjares de Castilla a fines de la Edad Media: una aproximación a su realidad jurídica y social». En García Fernández, Manuel (coord.). En la Europa medieval. Mujeres con historia, mujeres de leyenda. Siglos XIII-XVI. Sevilla: Editorial Universidad de Sevilla, 2019, p. 287, nota 44. 
Juicio Final para los mudéjares ${ }^{62}$. El más popular fue sin duda el Breviario sunní de Yça de Segovia, cuyos manuscritos presentan dos familias de variantes, una más antigua, que puede retrotraerse al manuscrito original de propio Yça, y por tanto de «etapa mudéjar», y otra desarrollada en la segunda mitad del siglo xvi por parte de los moriscos ${ }^{63}$. Yça de Segovia utilizó como fuentes principales para su breviario el Kitāb al-Tafrì̀ de Ibn alŶallāb y la Risāla fí l-fiqh de al-Qayrawānī, de las que ya hemos hablado para el periodo islámico, pero las matiza refiriéndose a las prácticas de sus contemporáneos, sea porque no las encuentra en los manuales, o porque le parecen poco apropiadas. A los breviarios se une el texto denominado Demandas de Muça (o $M \bar{u} s \bar{a}$ ), que podría traducirse como «las preguntas de Moisés», y que en otros manuscritos se transmite como «alhadiz de Muçe», un diálogo que explica las principales creencias y prácticas del Islam para la formación de los creyentes, que fue ampliamente transmitido tanto en el periodo andalusí como en el mudéjar. La relevancia de este relato en la enseñanza de la religión entre los mudéjares ha sido recientemente puesta de relieve por Colominas ${ }^{64}$.

La otra fuente es aún más reveladora, pues, al mencionar de pasada los rituales funerarios, nos deja constancia de las prácticas reales de la comunidad toledana y de la aplicación de la teoría que se halla en las fuentes anteriores. Se trata de un libro de actas en árabe de las reuniones de los hermanos (al-ajwān) pertenecientes a "la cofradía de yami“al-Wadī'a», es decir, de la mezquita toledana conocida en castellano como de las Tornerías o del Solarejo, única que conocemos activa en la ciudad en la época que nos concierne $^{65}$. El grupo debía estar de alguna manera vinculado a la mezquita, situada en

62 El ms. aljamiado de Ocańa, compilación de hadices para el uso de un alfaquí de esta ciudad datado en el siglo xv, y cuya procedencia pudo ser algún escritorio mudéjar de Toledo o Zaragoza, se refiere a las creencias que debía tener el musulmán sobre ella. Hofman Vannus, Iris. Historias religiosas musulmanas en el manuscrito mudéjar-morisco de Ocaña. Edición y estudio. Madrid: Universidad Complutense, 2004, fols. $7 \mathrm{v}$-28r. Sobre el hallazgo del manuscrito, ÍDEM. «El manuscrito mudéjar-morisco de Ocańa, un breviario musulmán recuperado». En 30 años de mudejarismo: memoria y futuro (1975-2005). Actas del X Simposio Internacional de Mudejarismo. Teruel: Centro de Estudios Mudéjares, 2007, pp. 593-604.

63 En este trabajo se citan las dos ramas de manuscritos espańoles, a través del Ms. 2076 de la Biblioteca Nacional de Madrid (fechado hacia 1550, a partir de ahora BNM 2076), considerado por Wiegers la transmisión más antigua, cit. Wiegers, Gerard. Islamic Literature in Spanish and Aljamiado. Yça of Segovia, his Antecedents and Successors. Leiden: Brill, 1994, p. 115; y el procedente de la Biblioteca Tomás Navarro Tomás del CSIC en Madrid, RESC 60 (anteriormente Junta-60), datado hacia 1595-1612 por las marcas de papel (a partir de ahora TNT 60), cit. WIEgers, Islamic Literature, pp. 119-120. Véase también ÍDEM, «Breviario Çunní de Iça de Gebir». En Mateos Paramio, Alfredo y Villaverde Amieva, Juan Carlos (eds.). Memoria de los moriscos: escritos y relatos de una diáspora cultural. Madrid: Sociedad Estatal de Conmemoraciones Culturales, 2010, pp. 130-132.

64 Se encuentra también en el manuscrito TNT 60, fols. 91r-103v; otra versión en GuiJarro HorTELANO, Emma María. La maternidad en las comunidades mudéjar y morisca según un manuscrito aljamiadomorisco aragonés. Estudio y edición critica (Códice T-8 BRAH). Teruel: Centro de Estudios Mudéjares, 2010, pp. 455-474; Colominas Aparicio, Mònica. The Religious Polemics of the Muslims of Late Medieval Christian Iberia: Identity and Religious Authority in Mudejar Islam. Leiden: Brill, 2018, pp. 79-82.

65 Echevarría Arsuaga, Ana y Mayor, Rafael. «Las actas de reunión de una cofradía islámica de Toledo, una fuente árabe para el estudio de los mudéjares castellanos: años 1402 a 1414». Boletín de la Real Academia de la Historia, 2010, vol. CCVII, n. ${ }^{\circ}$ 2, pp. 257-293. Sobre el funcionamiento de la cofradía y sus fines, Mayor y Echevarría Arsuaga, «Hermanos y cofrades». Sobre los usos funerarios de la cofradía y su conexión con cofradías funerarias anteriores, véase ECHEVARRíA, «Islamic Confraternities». 
ENTERRAMIENTOS Y RITOS FUNERARIOS ISLÁMICOS:

DE LO ANDALUSí A LO MUDÉJAR A TRAVÉS DEL CASO TOLEDANO

ANA ECHEVARRÍA

plena zona comercial, cuyo nombre árabe se desconocía, y que podría ser este al-Wadía de los documentos. La cofradía puede fecharse con seguridad entre 1402 y 1420, fechas entre las cuales se celebran las reuniones, aunque su existencia pudo durar muchos más años. Las actas tratan sobre todo asuntos internos de funcionamiento y ritual, recogen las limosnas debidas y las reuniones para practicar el dhikr y celebrar banquetes de confraternidad, y estipulan las cuestiones más públicas del entierro y los funerales, aquellas que afectaban a la interacción entre las familias de la comunidad -la del difunto y las de los demás miembros de la cofradía-, así como a las obligaciones sociales y religiosas respecto al enterramiento y acompañamiento de sus miembros a la tumba. Contrastando estos dos tipos de fuentes podemos hacernos una idea bastante aproximada de los rituales que se debían llevar a cabo en el Toledo mudéjar.

El proceso del enterramiento se considera como parte de las obligaciones sociales del musulmán respecto a sus correligionarios, hasta el punto de que el mérito de las tareas asociadas al difunto y de los rituales religiosos conducentes a conservar su cuerpo para el Día del Juicio y su posterior salvación se extendía a los participantes. Esta importancia se refleja en el texto conocido como Demandas de Muça. En él, Moisés se dirige a Dios, preguntándole qué premio recibirán los fieles que participen en los rituales de preparación del difunto: el baño, la oración sobre el fallecido y la excavación de la fosa. Todos ellos se consideran ocupaciones meritorias, que conllevan respectivamente la limpieza de los pecados, la oración de los ángeles y el disponer de una vivienda en el Paraíso, para el que las realice ${ }^{66}$.

La pureza y la legalidad de los implicados en los procedimientos de lavado y preparación del cadáver eran esenciales para mantener la cohesión religiosa entre los musulmanes, y no debían ser contaminados por costumbres cristianas. La cuestión de los grados de parentesco, el sexo y la adscripción religiosa de los que podían proceder a la limpieza del cadáver, así como qué tipo de abluciones eran necesarias antes y después de la manipulación del difunto, eran los temas más tratados. En general, Yça de Segovia no recomienda un número fijo de abluciones, no se refiere a los perfumes que podían ser utilizados, que sí eran tratados con más detenimiento por al-Qayrawānī y al-Tafrì', así como qué partes del cuerpo podían ser vistas por quién exactamente:

Y en el vañar del non aya tasa çierta, pero bañele quien mejor supiere como sea limpio y espremido su cuerpo cubiertamente, inclinado sobre el y echando agua y vańandole como quien vańa, asi y con su alguado, bolbiendole de cabo a cabo, y no empesse que vañe el hombre a su muger, y la muger a su marido, y la muger al moçuelo de poca edad. Y no quiten al difunto cavello, ni circunçision, ni uñas, ni cosa de su cuerpo, salvo a limpiarle quanto $\operatorname{podran}^{67}$.

${ }^{66}$ «Dijo Mūsā: - ¡Yāa, mi Señor! ¿y qué gualardón habrá quien bañará un muerto? Dijo Allāh: - Que lavaré lo que habrá sobre él de sus pecados. Dijo Mūsā: - ¡Y Yā, Señor! ¿qué gualardón habrá quien fará aș̣̦ala sobre el muerto? Dijo Allāh: - Que harán așșala sobre él mis almalakes el día que morirá. Dijo Mūsā: - ¡Yãa, mi Señor! ¿qué gualardón habrá quien cabará la fuesa? Dijo Allāh: - Que fraguaré para él una alqasar en la alğanna». Guijarro Hortelano, La maternidad, p. 468; YÇA De SEgovia, TNT 60, fol. 101r.

67 YÇA DE SEGOVIA, BNM 2076, fol. 28r. El texto de la versión morisca presenta ligeras diferencias en su redacción, tanto por la evolución lingüística como por la precisión de algunos rituales, que se explican 
Sobre el tema de las mortajas, el Breviario sunní vuelve a citar las tradiciones canónicas ya recogidas por al-Qayrawānī:

Y amortajen al defuncto en tres lienzos, o çinco, o siete blancas tiras o camisas o alcandoras una sobre otra, de grado en grado. E non amortajen en seda ni en sirgo nin le metan oro ni plata ni otras joyas, y ponganle olores buenos entre su mortaja y cuerpo y lugares del açuchud $^{68}$.

Curiosamente, las actas de la cofradía no hacen ninguna referencia a la participación de sus miembros en todas las actividades en torno al difunto a la hora de su amortajamiento, ni seńalan el que sea necesario contribuir a los gastos derivados de la compra de telas lujosas para el sudario, por lo que debemos suponer que cada familia tenía la capacidad de proveer sobre ello sin mayores dificultades y sin incurrir en las deudas descritas en obras de épocas anteriores ${ }^{69}$.

Las oraciones sobre el muerto (salāt al-ŷanäiz) estaban cuidadosamente estipuladas y debían recitarse en tres lugares diferentes: en la propia casa, suponemos que durante el velatorio; delante de la mezquita, al pasar por allí el cortejo funerario pero sin entrar en el edificio -normalmente era el imán el que salía a recibir el féretro, en el patio de la mezquita-; y finalmente en el cementerio. La lectura de azoras del Corán en la cabecera del difunto, una innovación respecto a la escuela malikí temprana, es criticada en el Breviario sunni:

Acuerden al que está a la muerte a nombrar Alla y non se le debe açercar a el quien non tenga atahor de que fallesçe. Y dieron lugar algunos sabios leer a su cabeçera y non fue usado ni acordado por Melique, nin den voçes ni gritos, mas paçientemente quanto mas podran lloren calladamente ${ }^{70}$.

Aunque los propios tratados legales y religiosos reconocían que no había una oración precisa para realizar las plegarias por los difuntos - «y no es en ella liyenda» ${ }^{71}$, diría al-Tafri - - , en realidad el uso práctico determinó la canonización del texto transmitido por al-Qayrawānī, recogido posteriormente por Yça de Segovia, con ligeras variaciones debidas solo a su transmisión en las distintas lenguas: en árabe, su traducción castellana, o aljamiado. Dado que en muchos casos la plegaria se podía realizar en casa durante la vigilia, fuera de la mezquita acompańando al cortejo, o en el cementerio, y que no siempre estaba presidida por el imán ni el alfaquí, era necesario asegurar su validez y utilidad, y

más claramente: «En el bañar del muerto no ay tasa çierta, mas bañelo quien mejor supiere demanera que quede linpio, y primanle su bientre por que salga la rrodeça que se le rremobio con las congoxas de la muerte, cubierto su cuerpo con un linçuelo. Echen agua sobre él bañandole como quando se baña el hombre en su alguadoc, bolbiendole de un cabo a otro, tanbien para que bañe el hombre a su muger y la muger a su marido y la muger al mochacho quando es de poca edad. No le quiten al muerto cabellos ni lo aten ni le corten sus uñas, ni cosa de su cuerpo, sino a limpiarlo quanto podrán». TNT 60, fol. 26r.

68 YÇA DE SEGOVIA, BNM 2076, fol. 28r.

69 Aвboud-HagGar, El tratado jurídico, vol. II, pp. 173-174.

70 YÇa de Segovia, BNM 2076, fol. 28r; basado en AL-QAyrawĀnī, Compendio, pp. 87-91.

71 Aвboud-Haggar, El tratado jurídico, vol. II, p. 169. 
ENTERRAMIENTOS Y RITOS FUNERARIOS ISLÁMICOS:

DE LO ANDALUSí A LO MUDÉJAR A TRAVÉS DEL CASO TOLEDANO

ANA ECHEVARRÍA

quizá por ello se prefirió transmitir una fórmula determinada, que podía ser acompañada de la lectura de determinadas azoras del Corán. La continuidad de la transmisión desde las copias árabes de al-Qayrawānī, que tuvieron una rápida difusión en la Península durante el siglo XII, hasta el Breviario sunni en sus versiones castellana y aljamiada en el XV, y finalmente a los manuscritos misceláneos de los moriscos que contienen instrucciones funerarias en el XVI, es una de las mejores pruebas de la participación de los mudéjares en esta cadena de transmisión de lo islámico hasta la expulsión de los moriscos de España ${ }^{72}$. El texto traducido al castellano sería el siguiente:

El açala del muerto.

Las loores son ad Alla que mata y abibiga y aberiguara los defunctos, a el es la grandeza y poderio y laudamiento y es sobre toda cosa poderoso.

Señor Alla allega sobre Muhamad y sobre los de Muhamad y semejantes laudaçiones, y dirá: Señor, este este (sic) es tu siervo, este fijo de tu siervo, tu lo criaste y lo mantubiste, y lo mataste y lo altivaras y tu sabes su secreto y paladino. Venimos a te rrogar por el, Señor, a ti nos avesindamos que tu eres complidor de omenaje, Señor, defiendele del tentamiento de la fuesa [fosa] e de las penas de chehenema (sic).

Señor Alla, perdonale y onrra su morada y ensancha su entrada, y labalo y alimpialo de sus culpas, y dale mejor casa y mejor compañia de la que tenia.

Señor Alla, si fue bueno creçe su bondad y si fue malo perdonale sus pecados, que a ti non empeçe, Señor, es pobre ante ti y tu eres rico sin el.

Señor Alla, afirma la su lengua al tiempo de la pregunta en su fuesa: que no tartalee en lo que non a fuerça sino contigo, Señor Alla, non nos harames su galardon ni nos retientes despuesdel.

Esto as de deçir tres vezes, y en fin de cada vez Allahu aquebar, que sera dichas quatro vezes, y asi dichas todas quatro diras: Señor Alla, perdona a nuestros bivos y nuestros muertos y a los presentes y ausentes, grandes y menores, machos y fembras, que tu sabes nuestros fines y asentamientos, y a nuestros padres y antepasados de los creyentes moros y moras creyentes, y creyentes bivos y muertos.

Señor Alla, a quien dieres /f. 29r/ dias de vida de nos seya en la creyençia firme y a quien dieres fin amatalo en la creençia y danos buena ventura en tu encontramiento y buena fin a la muerte y sea nuestro descanso consolaçion de nuestras almas açalemolaley comy ${ }^{73}$.

No es fácil, a la vista de estas evidencias, saber si los mudéjares castellanos realizaban la oración por los difuntos en romance o en árabe en la segunda mitad del siglo xv.

La otra oración que se hizo habitual entre mudéjares y moriscos, esta vez por escrito, es la «carta de la muerte», con la que se le enterraba, en la que declaraba su fe y sus obras

72 Wiegers, Islamic Literature, pp. 122-123; VÁzquez, Miguel Ángel. Desde la penumbra de la fosa. La concepción de la muerte en la literatura aljamiado-morisca. Madrid: Trotta Editorial, 2007, pp. 182-187.

73 YÇa de SEgovia, BNM 2076, fol. 28r. La plegaria está recogida de forma más extensa en el manuscrito mudéjar de Ágreda, el otro único conservado en Castilla aparte del de Ocaña (El Escorial ms. 1880, fols. $90 \mathrm{v}-93 \mathrm{v}$ ), aunque en este aparece en árabe sin hacer ninguna alusión a los preparativos del difunto. Véase la edición y traducción de KADRI, Alice. Mudéjars et production en aljamía (XV siècle). Édition et étude du manuscrit d'Ágreda (Esc. 1880). Nantes, 2015, tesis inédita, vol. I, pp. 268-278; vol. II, pp. 175-179. Agradezco a la Dra. Kadri que me facilitara el acceso a su tesis, en la que realiza un estudio completo de la transmisión de esta plegaria. 
ante el interrogatorio de los ángeles Munqar y Nakir. La carta debía estar escrita en pergamino o papel, y puesta debajo de la cabeza, «entre la alkafan y su majilla, la derecha» ${ }^{74}$. El Breviario sunni denunciaba esta práctica: «algunos usaron avisar demanda y rrespuesta al defunto despues de enterrado, y non fue fecho nin acordado por Melique» ${ }^{75}$. Es decir, no estaba entre las plegarias canónicas que establecía el derecho malikí, y por tanto podría ser una innovación no autorizada. La aparición de fórmulas de esta plegaria en numerosos manuscritos aljamiados evidencia que su advertencia cayó en saco roto, y los mudéjares no arabófonos recurrieron a esta oración para asegurar que sus parientes tenían un pasaporte en árabe para superar el interrogatorio de los ángeles. Escrita en primera persona, comenzaba con la shahāda, una breve profesión de fe, seguida de varias jaculatorias en honor a Dios, y una serie de súplicas para que Dios no abandonase al difunto y le acompañase en la soledad de la tumba ${ }^{76}$.

Como hemos visto previamente, el lugar en el que se situaba el cementerio islámico de Toledo permitía el acceso fácilmente desde varias puertas de la ciudad, sin molestar excesivamente a las otras comunidades religiosas, y procurando una discreción que evitara los enfrentamientos entre unas y otras. Tanto en la comitiva fúnebre como en el cementerio la posición y el lugar de cada miembro de la comunidad estaba señalado: el féretro debía marchar de cara a la alquibla, con el imán o el alfaquí a la cabecera de la procesión, junto al féretro, seguido de los hombres, y después las mujeres que lo tenían permitido, que eran solo la esposa del difunto, su madre, sus hijas y sus hermanas ${ }^{77}$. Se recomienda solo la asistencia de la familia, dado que la discreción era una cualidad primordial para evitar llamar la atención de los cristianos sobre los rituales celebrados, por eso el papel de las plañideras quedó muy reducido respecto a lo que era costumbre en otros lugares del mundo islámico. Las palas para excavar la tumba eran portadas por miembros de la cofradía: «(en) esto deben participar los citados, en ser de los que llevan el féretro y la pala ${ }^{78}$. La participación de la comunidad en la excavación de las fosas formaba parte importante de su implicación en el traslado del difunto. Los manuales recomendaban que la fosa tuviese una profundidad determinada:

Y fagan la fuesa non fonda ni baxa, sea a medio estado de hombre, y entierrale en la lauda debaxo del ribaço que es fecho la fuesa a la fondesa, que ades un risco a cabo del alquibla que quepa el muerto descansadamente. Si la tierra lo sufre es mejor y adoses delante, donde non fagan lo de madera y hechen tierra dentro ${ }^{79}$.

74 Guijarro Hortelano, La maternidad, p. 482.

75 YÇA DE SEGovia, BNM 2076, fol. 29r.

76 VázQuez, Desde la penumbra, pp. 22, 112-113 y 181.

77 Echevarría Arsuaga y Mayor, «Las actas de reunión», pp. 273, 289; EcheVarría, «Islamic Confraternities», p. 353.

78 Se refiere a los priostes de la cofradía, el maestre Yusuf de Valladolid y el maestre Ahmad al-Sa ri, que estaban encargados también de los banquetes. Echevarría Arsuaga y Mayor, «Las actas de reunión», pp. 268, 284.

79 Yça de Segovia, TNT 60, fol. 29v; Al-Qayrawānī, Compendio, p. 90. 
Finalmente, las visitas al cementerio continuaban celebrándose, la primera noche y a los cuarenta días que marcaban el final del luto, momento hasta el cual los miembros de la cofradía estaban exentos de la participación en actos públicos de la misma y banquetes ${ }^{80}$. Tanto el Breviario sunn $i^{81}$ como el manuscrito mudéjar-morisco de Ocańa loaban a aquellos que visitaban las tumbas:

A quien visita un muerto en la primera noche con alguna limosna, si puede, y si no que rece dos arracas e invoque de parte del (muerto), Dios le aliviará lo que hay de castigo y de desolación. Dios recompensará a quien reza o da limosna con sesenta años ${ }^{82}$.

Aun así, a las mujeres se les exigía que mantuvieran un periodo de luto de cuatro meses después del fallecimiento de sus maridos ${ }^{83}$. Durante todo este tiempo, e incluso después, las visitas al cementerio fueron normales, a pesar de las reiteradas prohibiciones de los juristas, que rechazaban prácticas como la búsqueda de las bendiciones de los hombres piadosos enterrados allí, o el utilizar estas visitas como excusa para verse con miembros del sexo opuesto ${ }^{84}$. En Toledo, durante el funeral de un miembro de la comunidad, la familia de otro fallecido recientemente podía entrar en el camposanto para rezar la fätiḥa, la primera azora del Corán, lo que era desaconsejado ${ }^{85}$.

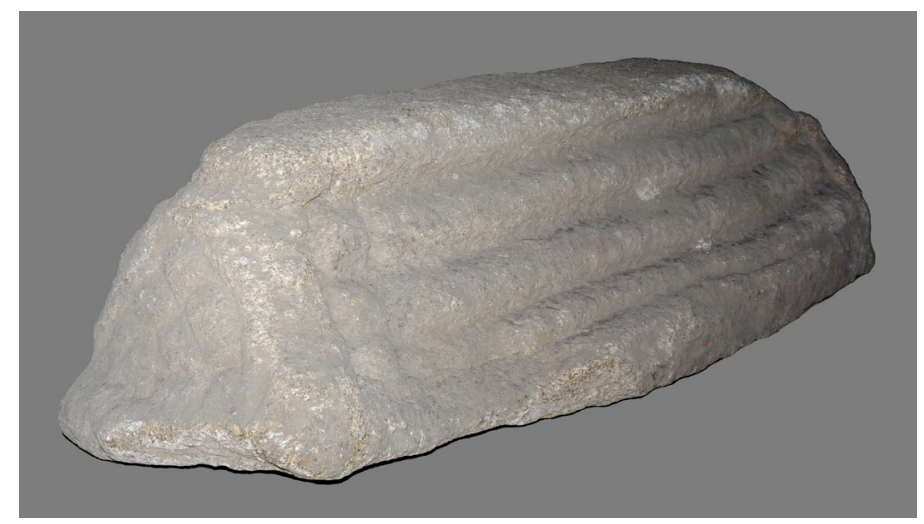

Figura 3. Estela funeraria mudéjar de Talavera de la Reina, siglos XIII-Xv. Toledo, Museo de Santa Cruz. (C) J. Jiménez Gadea / Museo de Santa Cruz.

80 «Otrosí (estuvieron de acuerdo en) que pueda abstenerse (de participar) de la citada comida en la boda citada sin caloña quien esté triste, el padre por el hijo y el hijo por el padre y los hermanos por los hermanos y cada uno de aquellos por \{su madre\}, desde el día en que falleció el muerto hasta completar treinta días». Echevarría Arsuaga y Mayor, «Las actas de reunión», pp. 268 y 284.

${ }^{81}$ "Y vesitar las fuesas secreto y cuytos sin llamar a otros es alhassana grande». YçA DE SEgOvia, BNM 2076, fol. 29v.

\footnotetext{
82 Hofman Vannus, Historias religiosas, fol. 62r.

83 EL-CheikH, "The gendering of 'death'», pp. 412-413.

84 Halevi, Muhammad's Grave, pp. 227 y 335.

85 Echevarría, «Islamic Confraternities», p. 363.
} 
Hasta ahora no ha aparecido ninguna estela perteneciente a las tumbas mudéjares de Toledo, como ocurre con las lápidas conocidas para Ávila y Talavera, salvo una inscripción asociada a Toledo por Lévi-Provençal de una tal Zahra, hija de Muhammad, datada en 1261-1262 ${ }^{86}$. Podríamos plantearnos si los enterramientos mudéjares tenían una influencia directa del resto del mundo islámico coetáneo, dada la tipología de sus lápidas y su factura tripartita o en cipos. En sus viajes hasta Alejandría y La Meca con motivo de la peregrinación, los mudéjares peninsulares tuvieron ocasión de contemplar numerosas tumbas y mausoleos, que dejaron recogidas en sus relatos de peregrinación (ribla-s) ${ }^{87}$. El caso más cercano a Toledo sería el del abulense Omar Patún, que en torno a 1493 realizó este viaje con numerosas paradas, intentando localizar y visitar las tumbas de personajes famosos y santones. Al llegar cerca de Damasco, dice:

A dos leguas de aqui pasamos por donde mataron al que le corto la cabeza. Aqui esta la fuesa de Hud -alayhi al-sallam-y dicen que estan aqui más de once mil alnabies, muchos de ellos se conocen por tener escribto su piedra a la cabeza ${ }^{88}$.

Esta referencia a las inscripciones en las tumbas desaparece en el resto de los monumentos que visita, donde es más escueto y se refiere a las qubbas que los coronaban. El hecho de que un mudéjar castellano se sintiera en la obligación de describir estos cementerios para sus correligionarios habla de una cultura funeraria común y reconocible, que reforzaría los vínculos con el resto de las comunidades que sí vivían en tierra islámica, pues tanto las tumbas de los sultanatos de Granada, Fez y Marrakech como las mamelucas o las otomanas tenían rasgos similares ${ }^{89}$.

EL FIN DEL CEMENTERIO MUDÉJAR

Como viene siendo habitual en cuestiones relativas al Islam, la primera ofensiva contra la visualización de los cementerios de otras religiones la encontramos para el área toledana en un sínodo local, el de Alcalá de 1481, que propone que «sean desfechos» todos los sepulcros hechos de mármol, piedra o similar y que marquen enterramientos

86 Jiménez Gadea, Echevarría Arsuaga, Tapia Sánchez y Villanueva Zubizarreta, La memoria de Alá, pp. 40-43, para la estela talaverana; el resto ya se han mencionado previamente. LÉVI-ProvençAL, Inscriptions arabes d'Espagne, p. 80.

87 También los monumentos funerarios. Ver Bulle, «L'architecture funéraire»; JimÉNEZ GadEA, Echevarría Arsuaga, Tapia Sánchez y Villanueva Zubizarreta, La memoria de Alá; Jiménez Gadea, Javier. "Las inscripciones árabes de El Barco de Ávila». En Echevarría Arsuaga, Ana y Fábregas García, Adela (eds.). De la alquería a la aljama. Madrid, 2015, pp. 197-226; y Jiménez Gadea y Villanueva Zubizarreta, "Elementos decorativos góticos»; Macias, Mértola. Le dernier port de la Méditérranée.

88 Casassas Canals, Xavier; Villanueva Zubizarreta, Olatz; Tapia Sánchez, Serafín de; Jiménez Gadea, Javier y Echevarría Arsuaga, Ana. De Ávila a La Meca. El relato del viaje de Omar Patún (14911495). Valladolid: Ediciones Universidad de Valladolid, 2017, pp. 83-84.

89 Echevarría, «Funerary practices», pp. 185-186. 
ENTERRAMIENTOS Y RITOS FUNERARIOS ISLÁMICOS:

DE LO ANDALUSí A LO MUDÉJAR A TRAVÉS DEL CASO TOLEDANO ANA ECHEVARRÍA

no cristianos y "que muestren diferencia de suelo» ${ }^{90}$. Esta normativa se aplicará sobre todo al cementerio de conversos instalado junto a San Bartolomé por el arzobispo Pedro Tenorio, que el arzobispo Carrillo cedería al Hospital de la Misericordia ${ }^{91}$. Aunque siguiendo al traslado de los mudéjares a una nueva morería situada cercana a la puerta de Zocodover, no parece muy factible que se pudiera ofender a la comunidad mudéjar de esa manera todavía.

Unos años después sí es más factible que se amortizara el cementerio, cuando Fernando el Católico dispuso que se pudiera vender la piedra del osario de los judíos -y quizá por extensión la del islámico, si ambos se encontraban adyacentes en el Circo-a los canteros toledanos para que pudiera ser utilizada en la construcción de las grandes obras arquitectónicas que se edificaron en la ciudad a principios del siglo XVI. Tras la adquisición de los terrenos en 1508 por parte del alcalde ordinario Alonso Azafrán ${ }^{92}$, un grupo de ciudadanos relacionados con Enrique Egas y Juan Guas había realizado la compra, que tuvo que deshacerse cuando el maestro descalificó la piedra por falta de calidad, aunque es posible que parte se utilizara como material de encofrado o cimientos en alguna de las construcciones.

Esta medida no resulta extraña, pues, como ha demostrado recientemente Pablo Ortego, otros cementerios de las minorías se vieron afectados por medidas similares tras los bautismos de 1502 e incluso antes ${ }^{93}$. En 1495, ocurría con el osario de Sahagún, que, al trasladarse los mudéjares a Valladolid, pasó a manos de Íñigo de Mendoza, criado del mayordomo mayor don Enrique Enríquez, y de Hernando de Ynara; el que correspondía a la morería sevillana de San Pedro fue embargado al día siguiente de publicarse la pragmática en 1502; el mismo año se vendería la piedra de los tres osarios de Ávila, el de San Nicolás, el de la morería de Sancti Spíritus y el de La Solana, para la construcción de las iglesias de San Nicolás, Santiago y Santa Ana; Pedro de Castilla, corregidor de Toledo, recibió como merced la antigua mezquita de las Tornerías con sus bienes antes de marzo de 1503, aunque no se habla del cementerio; en Plasencia el repostero de camas de los reyes, Pedro de Alderete, recibió la piedra del osario de los moros en 1504; y el de Valladolid pasó en 1505 a manos de Juan de Pedrosa, miembro del Consejo Real ${ }^{94}$. Algunos cementerios fueron objeto de acuerdos, como los de Huete, Madrid o Cuenca, pero, si el

90 Sánchez Herrero, José. Concilios provinciales y sínodos toledanos de los siglos XIV y XV. La religiosidad cristiana del clero y pueblo. Tenerife: Universidad de La Laguna, 1976, p. 334; cit. De JuAn García, «Los cementerios islámicos», p. 276.

91 Ruiz Taboada, La vida futura, p. 76.

92 Gómez-Menor Fuentes, José Carlos. «Algunos datos sobre el cementerio judío de Toledo». Sefarad, 1971, vol. 31, n. ${ }^{2}$, pp. 367-375: p. 369, citando la documentación del Archivo Histórico Provincial de Toledo, leg. 1228, que publica en pp. 373-375. Aunque se refiere al onsario de los judios, dada la proximidad de ambos es posible que incluyera parte de la piedra del islámico también. Cit. Ruiz TABOADA, La vida futura, p. 70 .

93 Ortego Rico, Pablo. «Cristianos y mudéjares ante la conversión de 1502. Mercedes a moros. Mercedes de bienes de moros». Espacio, Tiempo y Forma. Serie III, Historia Medieval, 2011, vol. 24, pp. 279318 .

94 Ortego Rico, "Cristianos y mudéjares», pp. 290-291 y 298-300. Publica el pleito de la Real Chancillería de Valladolid donde aparecen estas noticias, pp. 304-317. 
de Madrid fue reclamado por Beatriz Galindo para su monasterio de la Concepción pocos meses después, este último pasaría al Hospital de San Lázaro en 1514, tras ignorar los acuerdos alcanzados ${ }^{95}$. Así pues, podemos pensar que la piedra del cementerio toledano pasaría a ser utilizada en la ciudad, aunque por tratarse de mármol, bastante más delicado que el granito abulense, tuviera que emplearse para distintos fines.

A la espera de la aparición de nuevos hallazgos arqueológicos que revelen estos traslados, que solo serán posibles mediante una investigación sistemática de los muros y paredes de edificios construidos en las fechas en torno a los documentos de cesión de la piedra para la construcción, la conclusión general de este trabajo debe ser que los ritos funerarios de los mudéjares toledanos no sufrieron cambios importantes respecto a los de los musulmanes de la ciudad del periodo anterior, que vivían bajo dominio islámico. Lo que sí es necesario es una mejor diferenciación de los espacios funerarios de las tres comunidades religiosas. Las presiones inmobiliarias sobre la Vega Baja y otras zonas de la ciudad podrían hacer imposible la continuación de esta investigación si no se ponen los medios rápidamente, por lo que habría que proceder con velocidad y proteger este patrimonio tan vulnerable antes de que desaparezca por completo.

\section{REFERENCIAS BIBLIOGRÁficAS}

Abboud-Haggar, Soha (ed.). El tratado jurídico de al-Tafrī’ de Ibn al-Ǧallab. Manuscrito aljamiado de Almonacid de la Sierra. Zaragoza: Institución Fernando el Católico, 1999, 2 vols.

Alemán Aguilera, Inmaculada; Botella López, Miguel Cecilio y Jiménez Brobeil, Sylvia Alejandra. «Estudio antropológico de los restos óseos humanos aparecidos en el cementerio de La Rauda». Cuadernos de la Alhambra, 2000, vol. 36, pp. 181-190.

Alfonso X. Las Siete Partidas, ed. I. A. Corfis. Electronic Texts and Concordances of the Madison Corpus of Early Spanish Manuscripts, CD Rom. Madison, 1999.

Al-Qhyrawānī, 'Abd-Allāh Ibn Abī Zayd. Compendio de derecho islámico, trad. Jesús Riosalido. Madrid: Editorial Trotta, 1993.

Amador DE los Ríos, Rodrigo. Excavaciones en Toledo: memoria de los resultados obtenidos en las exploraciones y excavaciones practicadas en el año 1916. Madrid: Tip. de la Revista de Archivos, Bibliotecas y Museos, 1917.

Barroso Cabrera, Rafael y Morín de Pablos, Jorge. Regia Sedes Toletana. El Toledo visigodo a través de su escultura monumental. Toledo: Diputación de Toledo, 2007.

Bulle, Tuil. «L'architecture funéraire de Fès. Étude préliminaire d'une rawḍa anonyme». Arqueología Medieval, 2012, vol. 12, pp. 257-270.

Buresi, Pascal. La frontière entre chrétienté et Islam dans la Péninsule Ibérique. Du Tage à la Sierra Morena (fin XI'-milieu XIIT siècle). Paris: Publibook, 2004.

Burton-Page, J. «Makbara». Encyclopedia of Islam. 2. a ed. Leiden: Brill, 1991, vol. VI, pp. $122-$ 128.

Carrobles Santos, Jesús. "Toledo 284-546. Los orígenes de la capitalidad visigoda». En Regia sedes toletana. La topografía de la ciudad de Toledo en la tardía Antigüedad y Alta Edad Media. Toledo: Diputación de Toledo, 2007, pp. 45-92.

95 Ortego Rico, «Cristianos y mudéjares», p. 292. 
ENTERRAMIENTOS Y RITOS FUNERARIOS ISLÁMICOS: DE LO ANDALUSí A LO MUDÉJAR A TRAVÉS DEL CASO TOLEDANO ANA ECHEVARRÍA

Casassas Canals, Xavier; Villanueva Zubizarreta, Olatz; Tapia Sánchez, Serafín de; Jiménez Gadea, Javier y Echevarría Arsuaga, Ana. De Ávila a La Meca. El relato del viaje de Omar Patún (1491-1495). Valladolid: Ediciones Universidad de Valladolid, 2017.

Colominas Aparicio, Mònica. The Religious Polemics of the Muslims of Late Medieval Christian Iberia: Identity and Religious Authority in Mudejar Islam. Leiden: Brill, 2018.

De Juan Garcia, Antonio. Enterramientos musulmanes del circo romano de Toledo. Toledo: Consejería de Educación y Cultura, 1987.

De Juan García, Antonio. «Los cementerios islámicos de Toledo en la Edad Media». En Pacheco Jiménez, César (ed.). La muerte en el tiempo. Arqueología e historia del hecho funerario en la provincia de Toledo. Talavera de la Reina: Colectivo de Investigación Histórica Arrabal, 2016, pp. 265-291.

De Juan García, Antonio; Sáinz Pascual, M. ${ }^{a}$ Jesús y Sánchez-Palencia Ramos, Francisco Javier. «Excavación de urgencia en el cementerio islámico del circo romano de Toledo». En I Congreso de Historia de Castilla-La Mancha. Toledo: Junta de Comunidades de Castilla-La Mancha, 1988, vol. V, pp. 43-49.

Delgado Valero, Clara. «El cementerio musulmán de Toledo». En Simposio Toledo Hispanoárabe. Toledo: Univesidad de Castilla-La Mancha, 1986, pp. 187-191.

Delgado Valero, Clara. Materiales para el estudio morfológico y ornamental del arte islámico en Toledo. Toledo: Consejería de Educación y Cultura, 1987.

Delgado Valero, Clara. "Arqueología islámica en la ciudad de Toledo». En Actas del Primer Congreso de Arqueología de la provincia de Toledo. Toledo: Diputación Provincial de Toledo, 1990, pp. 407-432.

Delgado Valero, Clara. «El arte de Ifrīqiya y sus relaciones con distintos ámbitos del Mediterráneo: al-Andalus, Egipto y Sicilia». Al-Qantara, 1996, vol. 17, n. ${ }^{\circ} 2$, pp. 291-319.

Delgado Valero, Clara. «La estructura urbana de Toledo en la época islámica». En Regreso a Tulaytula. Guía del Toledo islámico (siglos VIII-XI). Toledo: Junta de Comunidades de Castilla-La Mancha, 1999, pp. 15-155.

Diem, Werner. The Living and the Dead in Islam. Studies in Arabic Epitaphs, 1: Epitaphs as Texts. Wiesbaden: Harrassowitz Verlag, 2004.

Echevarría Arsuaga, Ana. «La "mayoría” mudéjar en León y Castilla: legislación real y distribución de la población (siglos XI-XIII)». En la España Medieval, 2006, vol. 29, pp. 7-30.

EcheVArría Arsuaga, Ana. "Desplazamientos de población y movilidad social en los inicios del mudejarismo castellano». Actas del XI Congreso de Estudios Medievales. Ávila-León: Fundación Sánchez-Albornoz, 2009, pp. 499-520.

Echevarría, Ana. The City of the Three Mosques: Avila and its Muslims in the Middle Ages, trad. C. López Morillas. Wiesbaden: Reichert Verlag, 2011.

EcheVARría Arsuaga, Ana. «La política respecto al musulmán sometido y las limitaciones prácticas de la cruzada en tiempos de Fernando III (1199-1252)». En Ayala Martínez, Carlos de y Ríos Saloma, Martín F. (eds.). Fernando III, tiempo de cruzada. Madrid: Sílex, 2012, pp. 383-414.

EcheVArRíA, Ana. «Islamic Confraternities and Funerary Practices: Hallmarks of Mudejar Identity in the Iberian Peninsula?». Al-Masaq: Islam and the Medieval Mediterranean, 2013, vol. 25, n. ${ }^{\circ} 3$, pp. 345-368.

EchevarríA, Ana. «Funerary Practices in a Multi-Religious Context from the Iberian Peninsula to the Eastern Mediterranean». En Berner, Alexander; Henke, Jan-Marc; Lichtenberger, Achim; Morstadt, Bärbel \& Riedel, Anne (eds.). Das Mittelmeer und der Tod. Mediterrane Mobilität und Sepulkralkultur. Leiden: Ferdinand Schöningh, 2016, pp. 179-194. 
Echevarría Arsuaga, Ana y Mayor, Rafael. «Las actas de reunión de una cofradía islámica de Toledo, una fuente árabe para el estudio de los mudéjares castellanos: años 1402 a 1414». Boletín de la Real Academia de la Historia, 2010, vol. CCVII, n. ${ }^{\circ} 2$, pp. 257-293.

ECKer, Heather L. "Administradores mozárabes en Sevilla después de la conquista». En Sevilla 1248. Congreso Internacional Conmemorativo de la Conquista de la Ciudad de Sevilla por Fernando III. Madrid: Centro de Estudios Ramón Areces, 2000, pp. 821-838.

El-Cheikn, Nadia Maria. "Mourning and the Role of the Näiha». En Puente, Cristina de la (ed.). Identidades marginales Estudios onomásticos-biográficos de Al-Andalus, XIII. Madrid: Consejo Superior de Investigaciones Científicas, 2003, pp. 395-412.

El-Cheiкh, Nadia Maria. "The gendering of 'death' in Kitāb al 'iqd al-farìd». Al-Qantara, 2010, vol. XXXI, n. ${ }^{\circ}$ 2, pp. 411-436.

EstÉnAga Echevarría, Narciso. "Condición social de los mudéjares en Toledo durante la Edad Media». Real Academia de Bellas Artes y Ciencias Históricas de Toledo, 1924, vol. VI, n. ${ }^{\circ} 18-$ 19, pp. 5-27.

Fierro, Maribel. «El espacio de los muertos: fetuas andalusíes sobre tumbas y cementerios». En Fierro, Maribel; Van StaËVel, Jean-Pierre y Cressier, Patrice (eds.). Lurbanisme dans l'Occident musulman au Moyen Âge. Aspects juridiques. Madrid: Casa de Velázquez-Consejo Superior de Investigaciones Científicas, 2000, pp. 153-189.

García Luján, José Antonio. Privilegios reales de la Catedral de Toledo (1086-1462). Formación del patrimonio de la S.I.C.P. a través de las donaciones reales. 2 vols. Toledo: Caja de Ahorros Provincial de Toledo, 1982.

García SÁnchez de Pedro, Julián y Corral Vacheron, Isabelle. «La segunda al-ŷami de Tulaytula: la mezquita de El Salvador». En Mezquitas en Toledo, a la luz de los nuevos descubrimientos. Toledo: Consorcio de la Ciudad de Toledo, 2006, pp. 233-259.

GLICK, Thomas F. «Reading the Repartimientos: Modelling Settlement in the Wake of Conquest». En Meyerson, Mark D. \& English, Edward D. (eds.). Christians, Muslims and Jews in Medieval and Early Modern Spain. Interaction and Cultural Change. Notre Dame: University of Notre Dame Press, 2000, pp. 20-39.

Gómez-Menor Fuentes, José Carlos. «Algunos datos sobre el cementerio judío de Toledo». Sefarad, 1971, vol. 31, n. ${ }^{\circ}$ 2, pp. 367-375.

Gonnella, Julia. «Columns and Hieroglyphs: Magic Spolia in Medieval Islamic Architecture of Northern Syria». Muqarnas, 2010, vol. 27, pp. 103-120.

GonZález Palencia, Ángel. Los mozárabes de Toledo en los siglos XII y XIII. 4 vols. Madrid: Instituto Valencia de Don Juan, 1926-1930.

Guijarro Hortelano, Emma María. La maternidad en las comunidades mudéjar y morisca según un manuscrito aljamiado-morisco aragonés. Estudio y edición crítica (Códice T-8 BRAH). Teruel: Centro de Estudios Mudéjares, 2010.

Halevi, Leor. Muhammad's grave. Death Rites and the making of Islamic Society. New York: Columbia University Pres, 2007.

Hofman Vannus, Iris. Historias religiosas musulmanas en el manuscrito mudéjar-morisco de Ocaña. Edición y estudio. Madrid: Universidad Complutense, 2004.

Hofman VANnus, Iris. «El manuscrito mudéjar-morisco de Ocaña, un breviario musulmán recuperado». En 30 años de mudejarismo: memoria y futuro (1975-2005). Actas del X Simposio Internacional de Mudejarismo. Teruel: Centro de Estudios Mudéjares, 2007, pp. 593-604.

IbN 'IDĀRī AL-Marrakushī. La caída del califato de Córdoba y los reyes de Taifas (al-Bayân alMugrib), ed. F. Maíllo Salgado. Salamanca: Ediciones Universidad de Salamanca, 1993.

Ibn Al-Kardabus. Historia de al-Andalus, ed. F. Maíllo Salgado. Madrid: Akal, 1986. 
ENTERRAMIENTOS Y RITOS FUNERARIOS ISLÁMICOS:

DE LO ANDALUSí A LO MUDÉJAR A TRAVÉS DEL CASO TOLEDANO

ANA ECHEVARRÍA

Jiménez GadeA, Javier. «Acerca de cuatro inscripciones abulenses». Cuadernos Abulenses, 2002, vol. 31, pp. 25-71.

JimÉnEz GADEA, Javier. «Estelas funerarias islámicas de Ávila. Clasificación e inscripciones». Espacio, Tiempo y Forma. Serie I, Nueva Época. Prehistoria y Arqueología, 2009, vol. 2, pp. 221-267.

JimÉnEz GadeA, Javier. «Las inscripciones árabes de El Barco de Ávila». En Echevarría Arsuaga, Ana y Fábregas García, Adela (eds.). De la alquería a la aljama. Madrid, 2015, pp. 197-226.

Jiménez Gadea, Javier; Echevarría Arsuaga, Ana; Tapia Sánchez, Serafín de y Villanueva Zubizarreta, Olatz. La memoria de Alá. Mudéjares y moriscos de Avila. Valladolid: Castilla Ediciones, 2011.

Jiménez Gadea, Javier y Villanueva Zubizarreta, Olatz. «Elementos decorativos góticos en lo mudéjar abulense: las estelas funerarias». En Alonso Ruiz, Begoña (ed.). La Arquitectura Tardogótica castellana entre Europa y América. Madrid: Sílex, 2011, pp. 377-388.

KADRI, Alice. Mudéjars et production en aljamía (XV siècle). Édition et étude du manuscrit d'Ágreda (Esc. 1880). 2 vols. Nantes, 2015, tesis inédita.

León Muñoz, Alberto. ““¡Hombres! la promesa de Dios es verdadera”... El mundo funerario islámico en Córdoba (siglos viII-XIII)». Arqueología Medieval, 2008-2009, vol. 4-5, pp. 24-49.

LÉvi-Provençal, Évariste. Inscriptions arabes d'Espagne. Paris: Larose, 1931.

López Dapena, Asunción. Cuentas y gastos (1292-1294) del rey D. Sancho IV el Bravo (12841295). Córdoba: Monte de Piedad y Caja de Ahorros de Córdoba, 1984.

MaCias, Santiago. Mértola. Le dernier port de la Méditerranée: Catalogue de l'exposition "MértolaHistoire et Patrimoine (Ve-XIII siècles)». 3 vols. Mértola: Campo Arqueológico de Mértola, 2006.

Manzano Moreno, Eduardo. Conquistadores, emires y califas. Barcelona: Editorial Crítica, 2006.

Maquedano Carrasco, Bienvenido; Rojas Rodríguez, Juan Manuel y Sánchez Peláez, Elena I. «Nuevas aportaciones al conocimiento de las necrópolis medievales de la Vega Baja de Toledo (I)». Tulaytula. Revista de la Asociación de Amigos del Toledo Islámico, 2002, n.o 9, pp. $19-53$.

Marín, Manuela. «Des migrations forcées: les 'ulama' d'Al-Andalus face à la conquête chrétienne». En Наммам, M. (ed.). L'Occident musulman et l'Occident chrétien au Moyen Âge. Rabat: Publications de la Faculté des Letres et des Sciences Humaines, 1995, pp. 43-59.

Martín Rodríguez, José Luis. Orígenes de la Orden Militar de Santiago (1170-1195). Barcelona: Consejo Superior de Investigaciones Científicas, 1974.

Martínez Núñez, María Antonia. «Epigrafía funeraria en al-Andalus (siglos IX-XII)». Mélanges de la Casa de Velázquez, 2011, vol. 41, n. ${ }^{\circ}$ 1, pp. 181-209.

Mayor, Rafael y Echevarría Arsuaga, Ana. «Hermanos y cofrades en la aljama de Toledo a principios del siglo XV». Anaquel de Estudios Árabes, 2015, vol. 26, pp. 163-185.

Menéndez Pidal, Ramón y García Gómez, Emilio. «El conde mozárabe Sisnando Davídiz y la política de Alfonso VI con los Taifas». Al-Andalus, 1947, vol. XII, n.o 1, pp. 27-41.

MolÉNAT, Jean-Pierre. «Les mudéjars de Tolède: professions et localisations urbaines». En VI Simposio Internacional de Mudejarismo. Actas. Teruel: Instituto de Estudios Turolenses, 1995, pp. 429-435.

MolÉnAT, Jean-Pierre. Campagnes et monts de Tolède du XIt au XV siècle. Madrid: Casa de Velázquez, 1997.

MolÉNAT, Jean-Pierre. «Tolède à la fin du XI ${ }^{\mathrm{e}}$ siècle et au début du XII ${ }^{\mathrm{e}}$ : le problème de l'émigration ou de la permanence des musulmans». En Laliena Corbera, Carlos y Utrilla Utrilla, Juan F. (coords.). De Toledo a Huesca. Sociedades medievales en transición a finales del siglo XI (1080-1100). Zaragoza: Institución Fernando el Católico, 1998, pp. 101-111. 
MolÉNAT, Jean-Pierre. «Les sources chrétiennes sur l'histoire des 'musulmans soumis' dans la Péninsule Ibérique médiévale». En Sidarus, Adel (ed.). Fontes da História de al-Andalus e do Gharb. Lisboa: Centro de Estudos Africanos e Asiáticos, 2000, pp. 159-173.

MolÉNAT, Jean-Pierre. «L'élite mudéjare de Tolède aux XIV et Xve siècle». En Liber largitorius. Études d'histoire médiévale offertes à Pierre Toubert. Genève: Librairie Droz, 2003, pp. 563-577.

Molero Rodrigo, Isabel. Estudio bioantropológico de la Maqbara andalusí de Toledo (Siglos VIII-XI). Apuntes sobre el proceso de islamización. Madrid: Universidad Autónoma, 2017, tesis doctoral inédita.

Moreda Blanco, Francisco Javier y Serrano Noriega, Rosalía. «Excavación arqueológica en el cementerio de rito islámico de San Nicolás. Ávila (mayo-junio de 2002)». Oppidum, 2008, vol. 4, pp. 185-212.

Muñoz y Romero, Tomás. Colección de fueros municipales y cartas pueblas. Madrid: Imprenta de Don José María Alonso, 1847.

O'Callaghan, Joseph F. «The Mudejars of Castile and Portugal in the Twelfth and Thirteenth Centuries». En Powell, James M. (ed.). Muslims under Latin Rule (1100-1300). Princeton: Princeton University Press, 1990, pp. 11-56.

Онтоsнi, Tetsuya. «Cairene Cemeteries as Public Loci in Mamluk Egypt». Mamluk Studies Review, 2006, vol. X, pp. 85-231.

Ortego Rico, Pablo. «Cristianos y mudéjares ante la conversión de 1502. Mercedes a moros. Mercedes de bienes de moros». Espacio, Tiempo y Forma. Serie III, Historia Medieval, 2011, vol. 24, pp. 279-318.

Ortego Rico, Pablo. «Las mujeres mudéjares de Castilla a fines de la Edad Media: una aproximación a su realidad jurídica y social». En García Fernández, Manuel (coord.). En la Europa medieval. Mujeres con historia, mujeres de leyenda. Siglos XIII-XVI. Sevilla: Editorial Universidad de Sevilla, 2019, pp. 277-304.

Passini, Jean. Casas y casas principales urbanas. El espacio doméstico de Toledo a fines de la Edad Media. Toledo: Universidad de Castilla-La Mancha, 2004.

Peral Bejarano, Carmen. «Excavación y estudio de los cementerios urbanos andalusíes. Estado de la cuestión». En Torres Palomo y Acién Almansa (eds.). Estudios sobre cementerios islámicos andalusies. Málaga: Universidad de Málaga, 1995, pp. 7-10.

Pinilla Melguizo, Rafael. «Aportaciones al estudio de la topografía de la Córdoba islámica: almacabras». Qurtuba, 1997, vol. 2, pp. 175-214.

Porres Martín-Cleto, Julio. «¿Restos de una mezquita toledana?». Al-Andalus, 1978, vol. XLIII, n. ${ }^{\circ} 2$, pp. $457-459$.

Porres Martín-Cleto, Julio. «La mezquita toledana del Solarejo, llamada de las Tornerías». AlQantara, 1983, vol. IV, pp. 411-421.

Primera crónica general de España, ed. R. Menéndez Pidal y D. Catalán. Madrid: Atlas, 1977.

Ruiz Taвoada, Arturo. «La necrópolis medieval del Cerro de la Horca de Toledo». Sefarad, 2009, vol. 69 , n. ${ }^{\circ} 1$, pp. $25-41$.

Ruiz TABOADA, Arturo. La vida futura es para los devotos. La muerte en el Toledo medieval. Madrid: Ediciones de La Ergástula, 2013.

Ruiz TABOADA, Arturo. «Comments on Muslim, Jewish and Christian burial practices in medieval Toledo (Spain)». Journal of Islamic Archaeology, 2015, vol. 2, n.o 1, pp. 51-71.

Ruiz TAвоAdA, Arturo. «El límite sur de la necrópolis medieval judía del Cerro de la Horca y el problema del contacto con otros cementerios». Sefarad, 2016, vol. 76, n. ${ }^{\circ}$ 1, pp. 121-157.

SÁNCHez Herrero, José. Concilios provinciales y sinodos toledanos de los siglos XIV y XV. La religiosidad cristiana del clero y pueblo. Tenerife: Universidad de La Laguna, 1976. 
ENTERRAMIENTOS Y RITOS FUNERARIOS ISLÁMICOS:

DE LO ANDALUSÍ A LO MUDÉJAR A TRAVÉS DEL CASO TOLEDANO

ANA ECHEVARRÍA

SÁNChez Llorente, Margarita. «Memorial stone». En Museum with No Frontiers. Discover Islamic Art. http://www.museumwnf.org/thematicgallery [última consulta: 23/9/2019].

Schöller, Marco. The Living and the Dead in Islam. Studies in Arabic Epitaphs, 2: Epitaphs in Context. Wiesbaden: Harrassowitz Verlag, 2004.

Torres Balbás, Leopoldo, «Diario de obras en La Alhambra, 1925-1926». Cuadernos de La Alhambra, 1967, vol. 3, pp. 125-152.

Torres Palomo, María Paz y Acién Almansa, Manuel Pedro (eds.). Estudios sobre cementerios islámicos andalusies. Málaga: Universidad de Málaga, 1995.

Trelis Martí, Julio; Ortega Pérez, José Ramón; Reina Gómez, Inmaculada y Esquembre Bebia, Marco Aurelio. «El cementerio mudéjar del Raval (Crevillent-Alicante)». Arqueología y Territorio Medieval, 2009, vol. 16, pp. 179-216.

VAlor, Magdalena y GutiÉrrez, José Avelino (coords.). The Archaeology of Medieval Spain, 11001500. Sheffield: Equinox, 2014.

VÁzQuez, Miguel Ángel. Desde la penumbra de la fosa. La concepción de la muerte en la literatura aljamiado-morisca. Madrid: Trotta Editorial, 2007.

Villanueva Zubizarreta, Olatz. "Vivir y convivir bajo la señal de la media luna: mudéjares y moriscos en Valladolid». En Regueras Grande, Fernando y Sánchez del Barrio, Antonio (coords.). Arte mudéjar en la provincia de Valladolid. Valladolid: Diputación Provincial de Valladolid, 2007, pp. 19-33.

Villanueva Zubizarreta, Olatz. «Los mudéjares del norte de Castilla en vísperas del bautismo: expresiones religiosas de un Islam que no fue al-Ándalus». e-Humanista/Conversos, 2015, vol. 3, pp. 195-209.

Wiegers, Gerard. Islamic Literature in Spanish and Aljamiado. Yça of Segovia, his Antecedents and Successors. Leiden: Brill, 1994.

Wiegers, Gerard. «Breviario Çunní de Iça de Gebir». En Mateos Paramio, Alfredo y Villaverde Amieva, Juan Carlos (eds.). Memoria de los moriscos: escritos y relatos de una diáspora cultural. Madrid: Sociedad Estatal de Conmemoraciones Culturales, 2010, pp. 130-132. 